\title{
Trace Element Analysis of Minerals in Magmatic-Hydrothermal Ores by Laser Ablation Inductively-Coupled Plasma Mass Spectrometry: Approaches and Opportunities
}

\author{
Nigel Cook ${ }^{1, *}$, Cristiana L. Ciobanu ${ }^{1}$, Luke George ${ }^{2}$, Zhi-Yong Zhu ${ }^{1,3}$, Benjamin Wade ${ }^{4}$ and \\ Kathy Ehrig ${ }^{5}$ \\ 1 School of Chemical Engineering, University of Adelaide, Adelaide, SA 5005, Australia; \\ cristiana.ciobanu@adelaide.edu.au (C.L.C.); zhiyong.zhu@adelaide.edu.au (Z.-Y.Z.) \\ 2 School of Physical Sciences, University of Adelaide, Adelaide, SA 5005, Australia; \\ luke.george@adelaide.edu.au \\ 3 State Key Laboratory for Mineral Deposits Research, Department of Earth Sciences, Nanjing University, \\ Nanjing 210093, China \\ 4 Adelaide Microscopy, University of Adelaide, Adelaide, SA 5005, Australia; \\ benjamin.wade@adelaide.edu.au \\ 5 BHP Billiton Olympic Dam Operations, Adelaide, SA 5000, Australia; Kathy.J.Ehrig@bhpbilliton.com \\ * Correspondence: nigel.cook@adelaide.edu.au; Tel.: +61-8-8313-1096
}

Academic Editor: Antonio Simonetti

Received: 31 July 2016; Accepted: 16 August 2016; Published: 20 October 2016

\begin{abstract}
Laser ablation inductively-coupled plasma mass spectrometry (LA-ICP-MS) has rapidly established itself as the method of choice for generation of multi-element datasets for specific minerals, with broad applications in Earth science. Variation in absolute concentrations of different trace elements within common, widely distributed phases, such as pyrite, iron-oxides (magnetite and hematite), and key accessory minerals, such as apatite and titanite, can be particularly valuable for understanding processes of ore formation, and when trace element distributions vary systematically within a mineral system, for a vector approach in mineral exploration. LA-ICP-MS trace element data can assist in element deportment and geometallurgical studies, providing proof of which minerals host key elements of economic relevance, or elements that are deleterious to various metallurgical processes. This contribution reviews recent advances in LA-ICP-MS methodology, reference standards, the application of the method to new mineral matrices, outstanding analytical uncertainties that impact on the quality and usefulness of trace element data, and future applications of the technique. We illustrate how data interpretation is highly dependent on an adequate understanding of prevailing mineral textures, geological history, and in some cases, crystal structure.
\end{abstract}

Keywords: laser ablation inductively coupled plasma mass spectrometry; trace element data; ore genesis; sulphide minerals

\section{Introduction}

Significant advances have taken place in laser ablation inductively-coupled plasma mass spectrometry (LA-ICP-MS) over the past two decades ([1] and references therein). Instruments have become widely available in laboratories worldwide and the number of applications in Earth science has been greatly expanded by ongoing technological development, particularly with respect to analysis speed, resolution and sensitivity, and by the availability of reliable reference materials designed for specific purposes. The LA-ICP-MS method is also cost-effective compared to other techniques, such as secondary ion mass spectrometry (SIMS). For these reasons, LA-ICP-MS has rapidly established itself 
as the method of choice for generation of multi-element datasets for specific minerals. Applications have expanded from trace element 'spot' analysis to mapping of areas within a sample, greatly assisted by the widespread availability of software, such as iolite [2]. The LA-ICP-MS platform has also been developed to undertake stable (e.g., [3]) and radiogenic isotope analysis (e.g., [4,5]), and is also widely applied in geochronology to obtain U-Pb ages for zircon (e.g., [6]). LA-ICP-MS-based geochronology is rapidly being extended to other dateable minerals, including hematite [7,8], apatite [9], cassiterite [10], and epidote-group minerals [11].

This contribution reviews a number of recent advances both from a technological method-development and scientific problem-solving perspective. The focus of this contribution is on multi-trace element analysis for mineral characterisation and petrogenetic interpretation of magmatic-hydrothermal ore deposits. We highlight, drawing in part on our own published and previously unpublished data, the wide range of different mineral matrices that have been studied and the diversity of geological problems that can be addressed by accurate, reproducible trace element microanalysis. Secondly, this contribution discusses good analytical practice, stressing the need to have a detailed understanding of what has been analyzed and the potential limitations that area selection will have on data quality. We speculate on future developments and new applications. Recent advances in geochronology using LA-ICP-MS, $\mathrm{Pb}$ isotope analysis, and mapping of sulphur isotopes are covered elsewhere in this Special Issue $([8,12,13]$, respectively). Due to space limitations, LA-ICP-MS analysis of fluid inclusions (e.g., [14]), melt inclusions (e.g., [15]), and LA-ICP-MS trace element geothermobarometery (e.g., Ti-in-zircon [16], or Zr-in-titanite [17]), are also not covered here despite their great relevance to understanding the genesis of hydrothermal ore deposits.

\section{LA-ICP-MS Trace Element Microanalysis}

LA-ICP-MS applications in the Earth sciences are described in an extensive volume of literature. The reader is referred to Sylvester (2008) [1] for authoritative chapters on LA-ICP-MS hardware, the underlying principles of analysis, and outstanding issues. Although the overwhelming majority of LA-ICP-MS facilities (as is our own) are based around nanosecond LA-ICP-MS systems, one significant development over the past decade has been the emergence of femtosecond (fs) laser systems $[18,19]$. This has prompted concerns about the comparative performance of the two instrument types for geological materials (e.g., [20]).

For example, in a study of four glass reference materials, Ohata et al. (2014) [21] established that femto- and nanosecond LA-ICP-MS systems provide comparable results if Ca was used as an internal standard but significant deviations if Si-normalized fractionation was applied with fs laser ablation at $795 \mathrm{~nm}$. These deviations were attributed to the composition and/or particle size distribution of aerosols formed over the sampling interval and could be corrected for by modifying fluence and spot size. Wohlgemuth-Ueberwasser and Jochum (2015) [22] compared the performance of nanosecond solid state and excimer lasers with a $200 \mathrm{~nm}$ femtosecond laser for analysis of common sulphide minerals. They report significant differences in the degrees of melting, with no melting observed utilizing the femtosecond laser.

\subsection{Melts, Aerosols, Vapours and Mineral Decomposition}

The many recent technical developments in mass spectrometry that have enabled greater accuracies and sensitivity have also focused interest on matrix effects and the physical state of the ablated material. One factor considered to potentially influence data quality is heating and generation of melts or particles precipitated from aerosols and vaporized products of ablation (e.g., [23]) during laser ablation. If melts are generated, and these are inherently different, chemically to the reference material used for calibration, fractionation may be introduced that could lead to a reduction in precision [22].

An additional topic of concern is the potential for fractionation during transport of ablated material from sample to plasma to mass spectrometer, e.g., between iron and sulfur [24]. Fractionation 
can be caused at various stages, including chemical reaction processes (mineral decomposition, etc.) at the site of laser ablation, differential particle transport from the site of ablation as a function of particle size, preferential redeposition of particles of different size at the site of ablation or within the instrument, and selective ionization of some minerals in the ICP-MS. Each of these issues may be influenced by, and corrected for, by adjusting operating parameters of the LA-ICP-MS system (e.g., [23]), and judicious use of appropriate matrix-matched standards. There is also the issue of downhole fractionation, when operating in 'spot' mode, with fractionation increasing as a function of the aspect ratio of the crater.

\subsection{Reference Materials and Matrix Effects}

Use of appropriate matrix-matched reference standards is critical to enable correction for laser-induced fractionation during ablation, and thus reliable and reproducible quantitative outcomes (e.g., [25-32]). Table 1 lists reference materials commonly employed for LA-ICP-MS trace element analysis, matrices for which they have been applied, and key references regarding their suitability. The reader is referred to Reference [33] for a more extensive list of LA-ICP-MS reference materials. Although there are, to our knowledge, few published examples of comparative cross-laboratory or cross-standard testing (e.g., [34]), several publications have offered insights into the relative analytical accuracy that can be achieved. The use of multiple reference materials is encouraged [35]. New, alternative methods are also being sought to prepare suitable reference materials for analysis of elements not present in the more commonly used standards (e.g., [36]).

Table 1. Reference materials (RM) commonly employed for laser ablation inductively-coupled plasma mass spectrometry (LA-ICP-MS) trace element analysis of minerals in hydrothermal settings.

\begin{tabular}{|c|c|c|c|c|}
\hline Standard & Matrix Type & Suitability & Comments & References \\
\hline NIST-610, -612 & Synthetic glass & Silicates & $\begin{array}{l}\text { Widely used for silicates; } \\
\text { have been used as secondary } \\
\text { RM for Fe-oxides (low Fe } \\
\text { content but some trace } \\
\text { elements (e.g., As) not } \\
\text { present in primary RM such } \\
\text { as BHVO }\end{array}$ & $\begin{array}{l}\text { Norman et al. (1996) [29], } \\
\text { Jochum et al. (2011) [37], } \\
\text { Nadoll and Koenig [38] }\end{array}$ \\
\hline BCR-2G & Columbia River basalt glass & - & $\begin{array}{l}\text { Secondary RM for some } \\
\text { silicates }\end{array}$ & Wilson (1997) [39] \\
\hline GSE-1G, GSD-1G & Synthetic glasses & Fe-oxides & $\begin{array}{l}\text { Doped with most elements } \\
\text { found in Fe-oxides }\end{array}$ & Jochum et al. (2005) [40] \\
\hline BHVO-1 & Hawaiian basalt glass & - & Suitable RM for Fe-oxides & Flanagan (1976) [41] \\
\hline MASS-1 & Cold-pressed pellet & Sulphides & $\begin{array}{l}\text { Commercially available RM } \\
\text { for sulphides; } \\
\text { widely applied }\end{array}$ & $\begin{array}{l}\text { Wilson et al. (2002) [42], } \\
\text { Yuan et al. (2012) [43] }\end{array}$ \\
\hline $\begin{array}{l}(\mathrm{Fe}, \mathrm{Ni})_{1-x} \mathrm{~S} \text { and } \\
(\mathrm{Fe}, \mathrm{Cu})_{1-x} \mathrm{~S}\end{array}$ & Synthetic sulphides & Sulphides & - & $\begin{array}{l}\text { Wohlgemuth- } \\
\text { Ueberwasser et al. } \\
\text { (2007) [31] }\end{array}$ \\
\hline STDGL2b-2 & $\begin{array}{l}\text { Fused glass disk ( } 25 \% \mathrm{Zn} \\
\text { concentrate and } 75 \% \\
\text { pyrrhotite), mixture of } \\
\text { CANMET international } \\
\text { reference materials RTS-4 } \\
\text { and CZN-1 doped with } \\
\text { a range of trace elements }\end{array}$ & Sulphides & $\begin{array}{l}\text { Wide range of chalcophile, } \\
\text { siderophile and } \\
\text { lithophile elements }\end{array}$ & $\begin{array}{l}\text { Danyushevsky et al. } \\
\text { (2011) [32] }\end{array}$ \\
\hline NiS-3 & - & Sulphides & - & Gilbert et al. (2013) [34] \\
\hline IMER-1 & $\begin{array}{l}\text { Chalcogenide glass } \\
\left(\mathrm{Ge}_{28} \mathrm{Sb}_{12} \mathrm{~S}_{60}\right)\end{array}$ & Sulphides & $\begin{array}{l}4 \text { minor elements, } \\
34 \text { trace elements }\end{array}$ & Ding et al. (2012) [44] \\
\hline
\end{tabular}

In some cases, it may be advantageous to use two or more reference materials with different concentrations of the element to be used for internal calibration. For example, when analyzing trace elements in iron oxides, we prefer to use National Institute of Standards and Technology (NIST)-610 and 
one of the basalt glass standards (BHVO—basalt, Hawaiian volcano observatory or BCR-2G-basalt Columbia River glass; Table 1) since Fe, the only element that can be used as an internal standard for Fe-oxides, is much lower in NIST-610 ( $<1 \mathrm{wt} \%)$ relative to the natural basalt glasses. We also encourage users to compare LA-ICP-MS data for elements at concentrations of hundreds to thousands of ppm with electron probe microanalysis (EPMA) data on the same material as a further check on the validity of results.

It is clear, for example, that better quality analyses will be systematically obtainable for some elements than for others. In our experience with trace element analysis of sulphides, As, Se and $\mathrm{Hg}$ are among the more problematic elements, and can be difficult to completely remove from the ablation system, leading to high background counts for these elements. Samples suspected to contain high concentrations of these elements should only be run after others with lower concentrations. Lead can also be a problematic element. Higher background signals are encountered after analysis of galena or other $\mathrm{Pb}$-bearing minerals, compromising the detection of $\mathrm{Pb}$ in other minerals where the element is only a trace component. Similarly, arsenopyrite, a mineral that may be a source of valuable trace element data, should never be run before other sulphides containing only ppm concentrations of As. Thorough cleaning of the LA-ICP-MS system is in any case essential when switching between analysis of different minerals.

An appreciation of potential interferences remains an important issue associated with LA-ICP-MS analysis. This includes: (i) poly-atomic interferences such as the generation of argides if using Ar as the plasma gas (e.g., argides of $\mathrm{Cu}$ and $\mathrm{Ni}$ (e.g., [45])) that may interfere with $\mathrm{Pd}, \mathrm{Rh}, \mathrm{and} \mathrm{Ru}$ $\left({ }^{101} \mathrm{Ru}\right.$ with ${ }^{61} \mathrm{Ni}^{40} \mathrm{Ar}$, and so on); (ii) isobaric interferences between elements which have the same isotopic masses (e.g., ${ }^{108} \mathrm{Pd}$ with ${ }^{108} \mathrm{Cd},{ }^{115} \mathrm{In}$ with ${ }^{115} \mathrm{Sn}$ ); and (iii) multiple ionization interferences (generally less significant for trace element analysis). An understanding of potential interferences and isotopic proportions is necessary to know whether or not corrections need to be applied (for instance, correction of ${ }^{101} \mathrm{Ru}$ for ${ }^{61} \mathrm{Ni}^{40} \mathrm{Ar}$ when analyzing pentlandite, or ${ }^{115} \mathrm{In}$ for ${ }^{115} \mathrm{Sn}$ in stannite, Ni and Sn being major components of the two sulphides). Other potential interferences may not necessitate correction. For example, ${ }^{92} \mathrm{Zr}$ measurement in magnetite need not be corrected for ${ }^{52} \mathrm{Cr}^{40} \mathrm{Ar}$ since $\mathrm{Cr}$ is a minor component of magnetite and interference is thus negligible. The same would apply to analysis of In and Sn in sphalerite, since both elements are only minor components of that mineral, and any interference would be small, within the precision of the method. Interferences can be corrected for by careful analysis of blanks of known composition without the interfering element present. The list of potential interferences is large and, thus, beyond the scope of the present contribution.

When reporting trace element data, all users should provide full information on analytical methodology, including details of isotopes measured (with interference corrections as necessary), dwell times, external standard(s), internal calibration routines and precision and reproducibility of concentration data. It is also critical to report how the data were processed, both in terms of integrating segments of LA-ICP-MS depth profiles, and in terms of treatment of outliers and values below minimum detection limit to derive statistically meaningful data.

\subsection{What Is Being Analyzed?}

Compared to other techniques, notably electron probe microanalysis (EPMA) or SIMS, the volume of analyzed material by LA-ICP-MS is relatively large. Even with a small spot size of $15 \mu \mathrm{m}$, an ablation crater for a moderately hard mineral such as pyrite can be $20 \mu \mathrm{m}$ deep, giving an ablated volume of several thousand $\mu \mathrm{m}^{3}$. Softer minerals, such as galena or chalcopyrite, ablate far more rapidly. It is always prudent to ensure the ablated surface is free of inclusions prior to analysis but knowledge about the presence or absence of inclusions does not extend to depth within the section. Following guidelines to only analyze inclusion-free materials will, by and large, give reliable information on contained trace elements in a range of matrices. Nevertheless, by analyzing only 'clean' areas of a mineral, typically in its center, significant bias can be introduced into the dataset if that mineral is 
compositionally zoned (Figure 1). Problems associated with representative analysis of zoned grains are particularly accentuated when the grains are so small they do not accommodate multiple spot analyses.
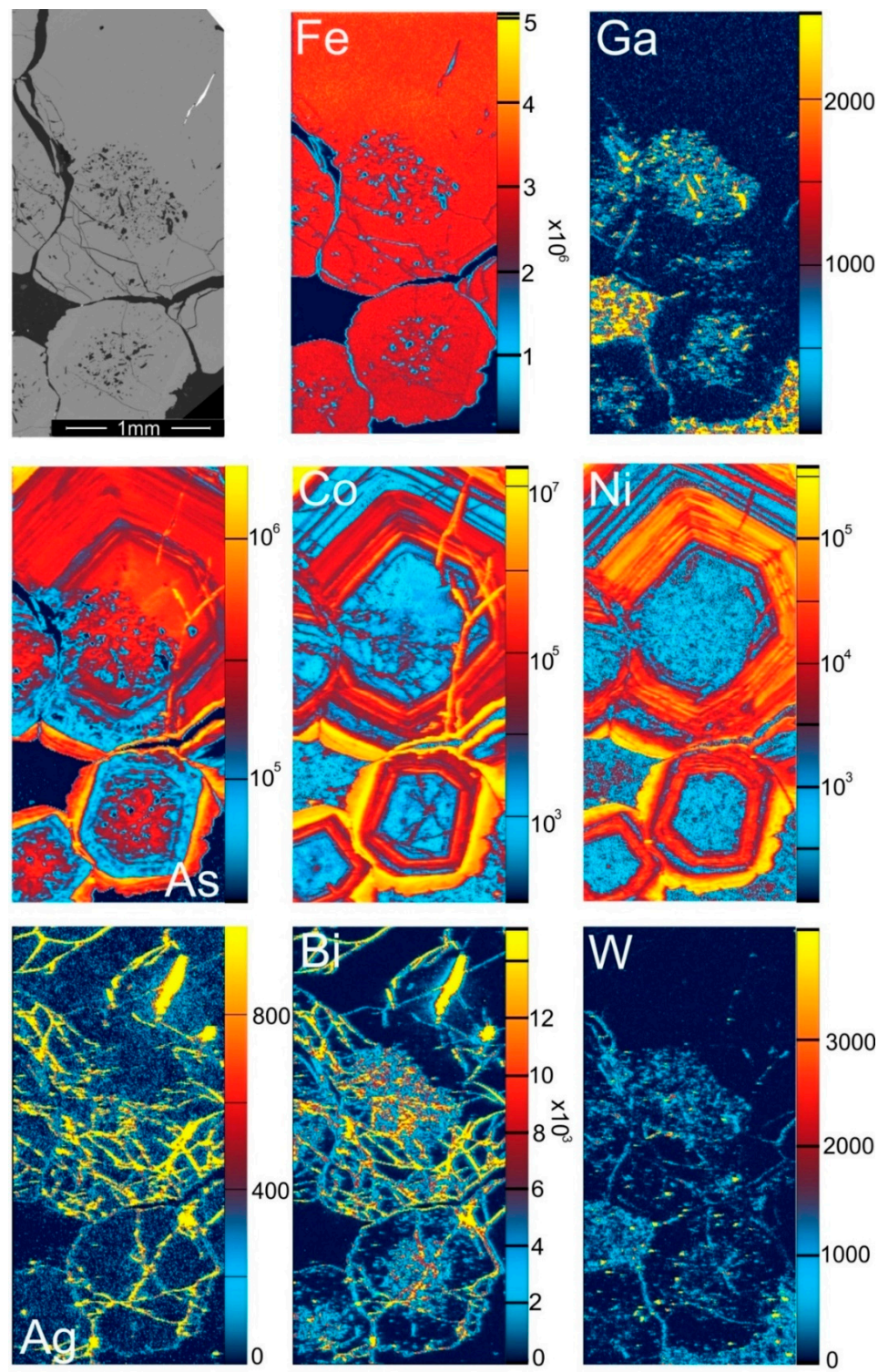

Figure 1. LA-ICP-MS maps of mm-sized pyrite grains displaying micron-scale oscillatory zoning. Note that, whereas As, Co and Ni occur in solid solution, within the pyrite grains and display concentric zoning, the map for Ga shows that element associated with microscopic silicate inclusions in the pyrite cores, and the maps for $\mathrm{Ag}, \mathrm{Bi}$ and $\mathrm{W}$ show these elements are distributed not within the zones but in crosscutting microfractures. The mapped area is shown as a backscatter electron image at upper left. Scales in counts-per-second. Measured isotopes: ${ }^{56} \mathrm{Fe},{ }^{69} \mathrm{Ga},{ }^{75} \mathrm{As},{ }^{59} \mathrm{Co},{ }^{60} \mathrm{Ni},{ }^{109} \mathrm{Ag},{ }^{2095} \mathrm{Bi},{ }^{182} \mathrm{~W}$.

A second, related problem, commonly observed but not restricted to studies of gold-bearing pyrite and arsenopyrite, is that areas of a grain with abundant microfractures, pores and non-sulphide inclusions, can contain significantly more Au than 'clean' areas without inclusions and/or pore-rich domains in pyrite and arsenopyrite (e.g., [46-48]). An assessment should therefore be made of whether grain-scale compositional heterogeneity (including chemical zoning) is present-either by creating a LA-ICP-MS map, or if simply by comparing absolute concentrations from a number of randomly positioned spot analyses. This assumes, however, that the micro-fractures or pores are visible. In some cases, the micro-fractures in particular will not be visible. Similarly, trace elements may 
be strongly concentrated along cleavage planes not visible under the SEM, and often only revealed by element mapping.

We also encourage LA-ICP-MS users to visually inspect laser craters after analysis-indications of possible inclusions can be seen in debris around the crater edge. In some cases, we have followed up LA-ICP-MS spot analysis by in-situ extraction of slices adjacent to the crater by focused ion beam (SEM) methods [49]. Subsequent investigation by transmission electron microscopy (TEM) allows the identity of what has been analyzed to be confirmed. A combined FIB-TEM approach can also be a powerful method to distinguish between nanoparticle-hosted and lattice-bound trace elements [50].

\subsection{Trace Element Mineral Signatures_TESIM}

A persistent question is whether analyzed elements are present in solid solution or as fine particle or nanoparticle mineral inclusions. Provided the particles are sufficiently large (roughly a few hundred $\mathrm{nm}$ in size), their presence will be recognized-and in many cases, their identity confirmed, on the down-hole laser ablation profiles. If the nanoparticles are fine enough and homogeneously distributed, however, it is impossible to recognize them on the downhole profiles, which will typically be smooth. Further investigation by transmission electron microscopy, as for example, done by Junge et al. (2015) [51], may help to understand if these elements are in the lattice, or occur as nanoparticle inclusions. Valuable information can nonetheless be obtained from analysis of areas within ore minerals that are known to include gangue or sub- $\mu \mathrm{m}$ to nanoscale inclusions of discrete minerals. We illustrate this with examples of chondrite-normalized REE + Y (REY) fractionation trends in hematite where the LA-ICP-MS spot size is significantly larger than the individual grains in the analyzed specimen (Figures 2 and 3 ).
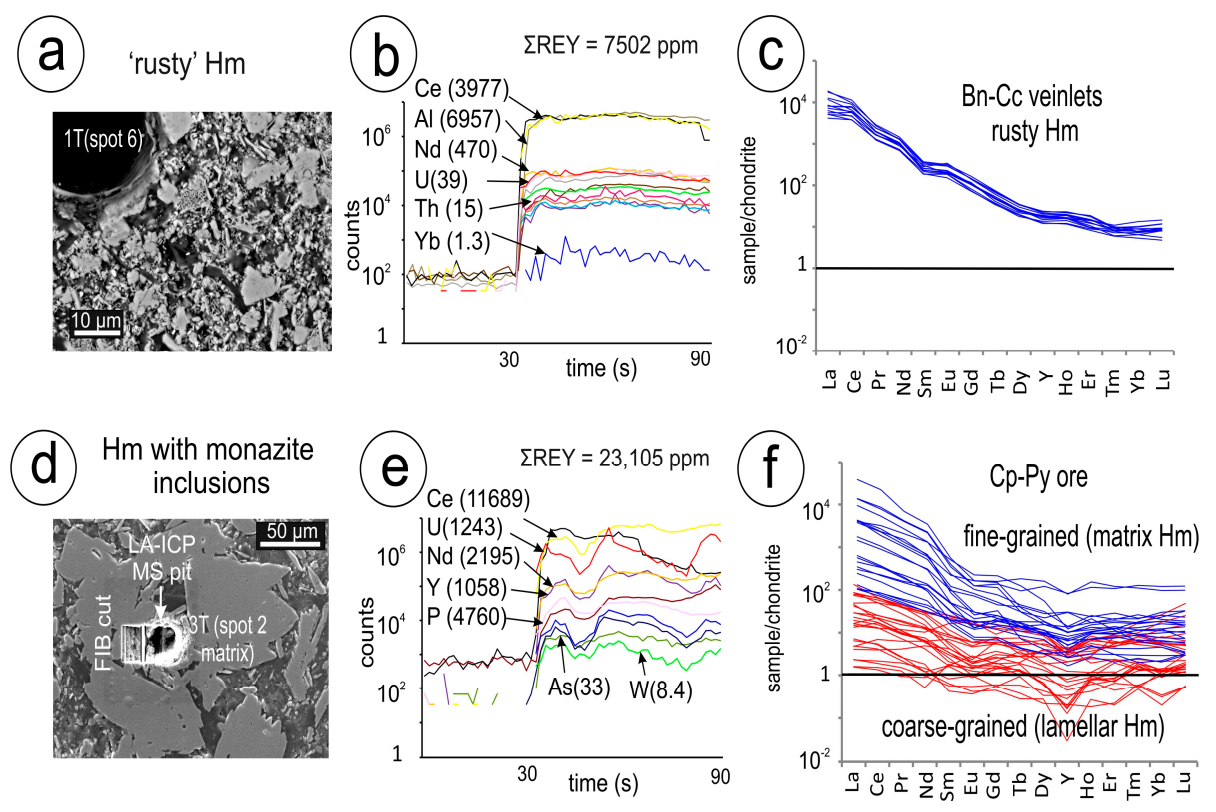

Figure 2. (a) Secondary electron (SE) image of fine-grained rusty hematite (Olympic Dam; OD). Note size of laser spot relative to grain size; (b) time-resolved depth profile showing 'flat' signals for most elements interpreted to he hosted in the hematite lattice; (c) chondrite-normalized REY fractionation trends for this type of hematite; note coherent, readily interpretable trends; (d) SE image of coarser hematite aggregate containing inclusions of monazite (see Figure 3a-d; OD); (e) time-resolved depth profile for spot in (d) showing rough signals indicative of inclusions during ablation. This hematite is not zoned with respect to trace elements; (f) chondrite-normalized REY fractionation trends for the hematite in the same sample shown in $(\mathrm{d}, \mathrm{e})$ separated by grain size. There is an increase in $\Sigma$ REY with the fine-grained hematite in the matrix, which shows similar REY profiles with the rusty hematite. Note however their wider range relatively to the finest, rusty hematite in (c). 
In Figure 2, we contrast LA-ICP-MS analyses of (i) rusty, finest-grained hematite (Figure 2a-c) and (ii) analysis of coarser hematite containing inclusions of monazite and at grain boundaries (Figure $2 \mathrm{~d}-\mathrm{f}$ ). Both cases show high $\Sigma$ REY (thousands of ppm, and $>2 \mathrm{wt} \%$ for the rusty and coarser hematite, respectively) but differ in the 'noisiness' of the LA-ICP-MS downhole profiles. In both cases, a proportion $(<10 \%)$ of the analyzed material is from gangue minerals, but the 'rusty' hematite clearly shows a smooth signal for individual elements and a highly reproducible chondrite-normalized REY fractionation trend. In the second case, spot analyses from the grain-boundaries and finer-grained hematite in the matrix are broadly comparable with those displayed by the rusty hematite trends but show much higher variability in terms of $\Sigma R E Y$, concordant with the observation of discrete REY-bearing minerals.
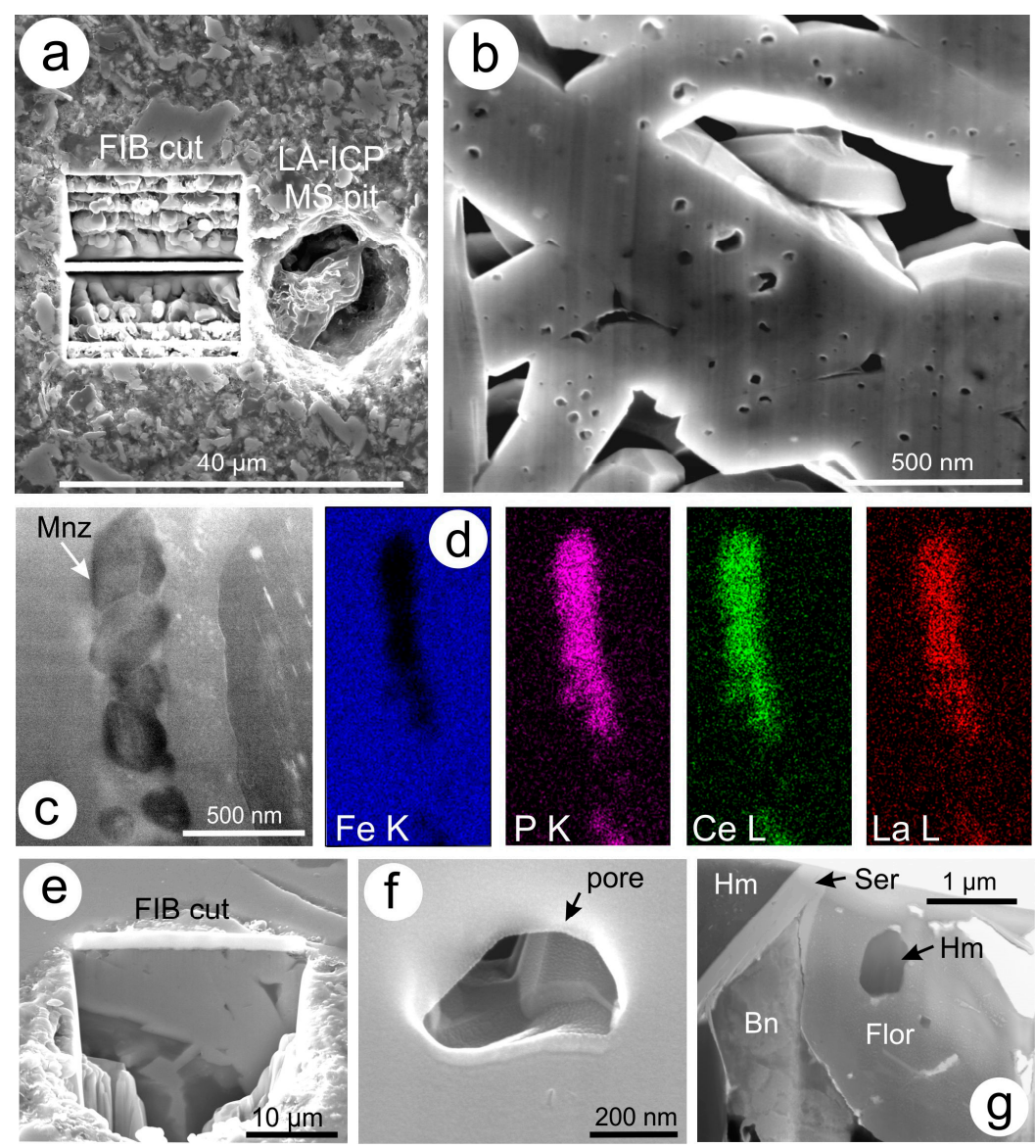

Figure 3. Mineral inclusions and porosity present in hematite from samples shown in Figure 2a,b SE images showing location of FIB-cut next to LA-ICP-MS spot in rusty hematite (a); and the presence of pores and inclusions within the sub- $\mu \mathrm{m}$ size lamellae (b); (c) FIB-Scanning Transmission Electron Image in Bright Field mode showing trails of sub- $\mu \mathrm{m}$ inclusions of monazite (Mnz) close to the grain boundary; (d) FIB-EDS maps of monazite grains in (c); (e,f) SE images showing distribution of pores and their morphology in hematite from (c) obtained after FIB-cross sectioning through the polished block; (g) Sub- $\mu \mathrm{m}$-sized inclusion of hematite $(\mathrm{Hm})$ in florencite (Flor) from a high-grade bornite (Bn)-bearing sample at OD. Ser-sericite.

FIB-SEM study of both types of hematite (Figure 3) feature pores and nanoscale inclusions. The latter differ in size in the rusty and coarser hematite, typically a few, or several hundred nm, respectively (Figure 3a-f). Some of these inclusions can be identified as discrete REE-minerals, notably the trail of monazite inclusions observed in the coarser hematite (Figure $3 c, d$ ). Note that the monazite grains are close to the margin of one of the lamellae, which is sputtered with nanoparticle-size 
inclusions and nanopores. We also draw attention to the fact that the margins of hematite lamellae in the rusty type do not contain abundant nanoscale REE-minerals attached to them but are instead rather 'clean' and the specimen is very vuggy (Figure 2b). This implies that the bulk of the measured REY content is hosted within the hematite itself. Lattice-bound elements can be released upon supersaturation and/or interaction with fluids, and can form discrete REE-bearing minerals within crystal lattice defects. Conversely, hematite can also occur as nanoscale inclusions (several hundred $\mathrm{nm}$ ) within REE-minerals (Figure 3g), re-emphasizing the strong genetic link between hematite and REY in iron oxide-copper-gold (IOCG) systems.

Based on this evidence, we conclude that trace element signatures in minerals (TESIM) can display consistency, and thus be used as meaningful geochemical tracers. This is true not only when the elements are lattice-bound but also when nanoscale inclusions are present, as long as the speciation of those inclusions does not vary widely.

\subsection{Mineral Textures}

No less important than an adequate knowledge of what has been analyzed, is an appreciation of the prevailing mineral textures, and how to compile compositional data for a given mineral into statistically meaningful groupings. Prior investigation of as large a volume of representative samples as possible by optical and scanning electron microscopy is strongly recommended prior to LA-ICP-MS microanalysis, to facilitate an adequate appreciation of multiple generations and overprinting (if present), features that might indicate compositional zoning, or evidence for mineral-mineral or mineral-fluid reactions. Single mineral grains may preserve compositionally or texturally-distinct domains that can be interpreted as multiple generations; examples include growth-zoned pyrite from metamorphosed ores that preserve pre-metamorphic grain cores (e.g., [52]), or skarn garnet recoding prograde and superposed retrograde growth cycles [53].

\subsection{Spots, Rasters and Element Maps}

The recent literature documents a number of different analytical approaches, notably the use of 'spots' (i.e., relatively deep craters) and 'trenches' (rasters; shallower ablation along a trajectory across a larger area). Each approach has its advantages and disadvantages and may be selected based on the target mineral and the inherent patterns to be analyzed. Spots and rasters may often be used in combination, each mode contributing information. Downhole fractionation is greater in 'spot' mode, and may affect the final results if not properly corrected for. Using raster analysis will decrease the spatial resolution of laser ablation in that the total surface area is generally larger. Spot analyses are commonly preferred when the minerals in question are small and/or compositionally zoned at the micron-size, and should be used (to keep the area analyzed as small as possible) if two or more distinct generations are present within that zoning pattern (e.g., an early core and later overgrowth). Raster analyses are certainly useful for showing variation across a single grain or assemblage, but there is always significant risk of mineral inclusions or other features that may influence the data. Raster analysis also has the advantage of allowing longer acquisition on grains that are sufficiently large and inclusion-free and can also contribute representative, average compositions for zoned minerals.

Trace element mapping by LA-ICP-MS has proven an extremely valuable technique to provide a visualization of trace element distributions within individual minerals or assemblages [54-58]. Element maps show concentration patterns with single zoned grains (Figure 1) and also facilitate a rapid visualization of the relative trace element concentrations and interpret partitioning trends among coexisting minerals (e.g., [59]).

Imaging is conducted by ablating sets of parallel lines in a grid across a sample surface. The laser spot size should match the distance between adjacent lines, and should be chosen based on the desired sensitivity of the elements of interest, as well as the desired spatial resolution. The authors typically use the open source software package 'iolite' [2] to compile and process trace element maps obtained by LA-ICP-MS data. Iolite is an add-in for the data analysis program Igor developed by WaveMetrics. 
Maps can be generated to provide either qualitative or quantitative information. Qualitative trace element maps are based only on measured counts per second (cps) for each element, and variation across a mapped area is displayed only in cps. As the ablation rate for different minerals can vary over orders of magnitude, the counts for elements within different minerals also vary greatly. Thus qualitative maps are able to disclose relative concentration variations across a mineral or assemblage (e.g., compositional zoning) but actual concentration values cannot be determined, and concentration intensity cannot be compared across different phases. Quantitative trace element maps determine actual trace element concentrations and these are often displayed on a parts per million (ppm) scale bar. Quantitative maps are able to reveal both trace element variation and actual trace element concentrations in a single mineral.

Difficulties arise, however, when attempting to quantify an entire assemblage comprising multiple distinct phases. Quantifying a map with iolite requires the selection and input of an internal standard. This tells the program the concentration of one element in the mapped area, allowing calculation of all other unknown element concentrations. If, however, the mapped area contains distinct phases of vastly different composition, a single internal standard often cannot be adequately selected.

Exceptions arise when mapping assemblages comprising distinct phases with comparable concentrations of a particular element. For example, when mapping base metal sulphide assemblages comprising sphalerite, galena and chalcopyrite, an average sulfur concentration value may be used as an approximate internal standard. Figure 4 shows three quantitative LA-ICP-MS maps of an assemblage comprising co-crystallized sphalerite, galena and chalcopyrite. The LA-ICP-MS maps were quantified by using $25 \mathrm{wt} \% \mathrm{~S}$ as the internal standard, a value representing an approximate average sulfur concentration for the assemblage. LA-ICP-MS spot analysis was also conducted around the margins of the mapped area for comparison. As can be seen, the LA-ICP-MS spot analyses closely match the concentrations displayed by the map. Some slight discrepancies are noted, although these are typically less than $10 \%$ of the spot values and are usually less than the uncertainty of ascribing a particular concentration value to a particular color on the map.
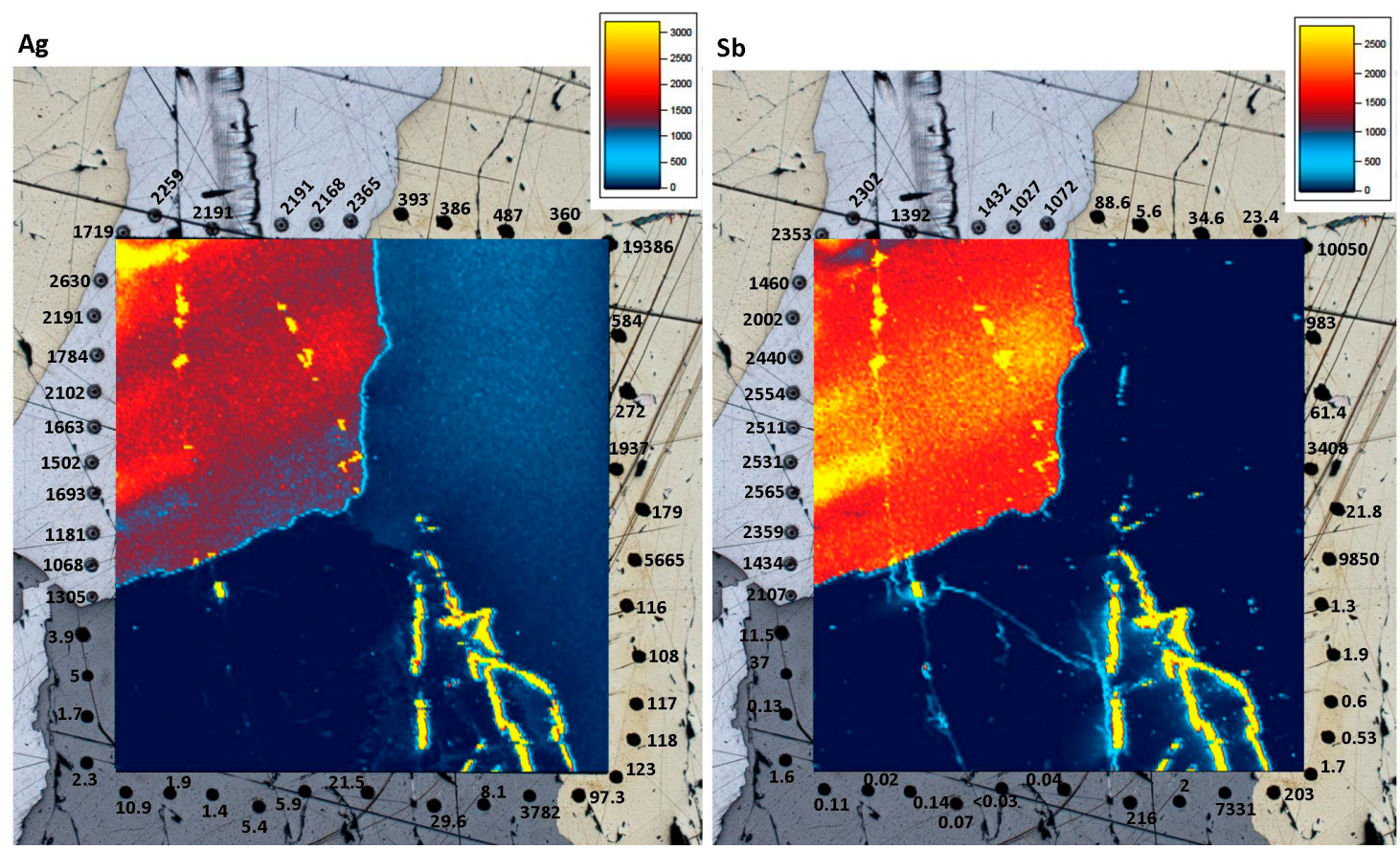

Figure 4. Cont. 


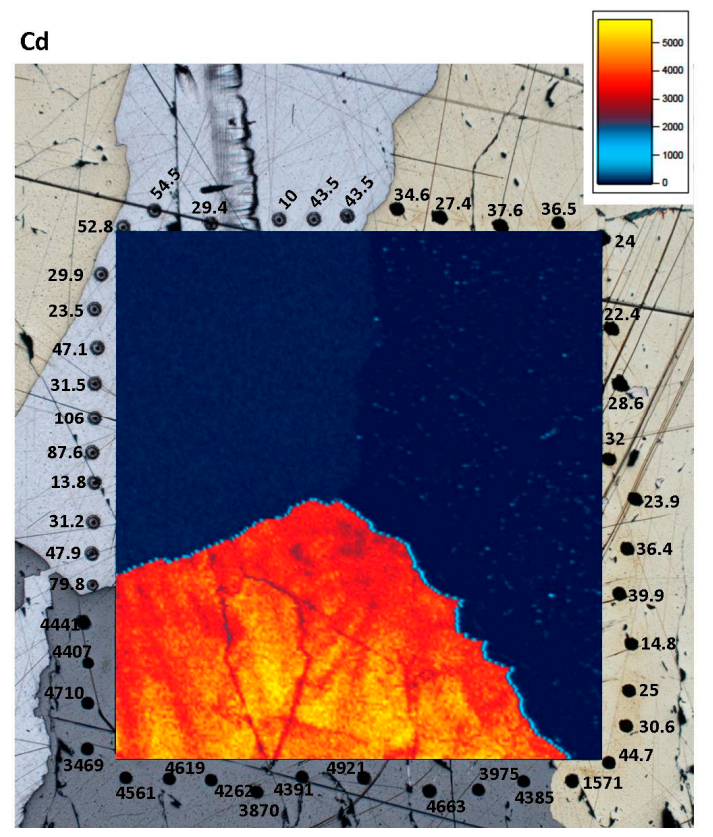

Figure 4. Comparison between quantitative LA-ICP-MS trace element maps ( $\mathrm{Ag}, \mathrm{Sb}$ and $\mathrm{Cd}$, ppm scales) of a galena (light grey)-sphalerite (dark grey)-chalcopyrite (yellow) assemblage with spot analyses (in ppm) immediately adjacent to the mapped area. An average value for sulfur was used as the internal standard to accommodate the three distinct minerals.

LA-ICP-MS maps generated via an average internal standard value are powerful in that they display approximately real concentration values that are comparable across different minerals in an assemblage. This is ideal for determining and comparing the distribution of trace elements in a multi-mineral assemblage. Care should, however, be taken in interpreting concentrations too rigidly. If trace element concentrations look similar in different phases, other methods should be employed to determine the preferred primary host of a particular trace element with confidence. If precise concentration values are required, LA-ICP-MS spot analysis should always accompany quantitative LA-ICP-MS mapping.

Two additional points are worth making. Firstly, if the scale of zonation within a given mineral is sufficiently fine (i.e., below the resolution of the element map), electron microprobe or SEM-EDS mapping might be a more suitable option. If the zoning is on a subscale below that of the microprobe beam, synchrotron-based methods (such as $\mu$-X-ray fluorescence spectrometry [60]) may be more appropriate. Secondly, map quality may be influenced by the orientation of the sample surface relative to zoning. Depth penetration during rastering will cause a blurring of the zoning pattern if that zoning is sharply inclined relative to the sample surface, with best results obtained if the zoning is perpendicular to the map.

\section{Trace Element Distributions in Common Minerals}

The range of mineral matrices in which trace element concentrations have been successfully measured by LA-ICP-MS has widened considerably in the past decade. These data, complemented by studies that have compared the trace element signatures of a particular mineral from different geological settings, provide a reasonably good understanding of which trace elements can enter specific mineral structures, and at approximately what range of concentrations. Currently available data is highly heterogeneous, keeping in mind that some minerals or mineral groups are far more thoroughly studied than others. 
Table 2 provides an overview of selected studies that have contributed, through LA-ICP-MS analysis, to current understanding of the trace element geochemistry of the common sulphides, iron-oxides, rock-forming silicates and a number of accessory minerals. As more data become available, a predictive understanding of the fundamental crystal-structural controls on element partitioning into specific minerals (e.g., critical metals in sphalerite [61], controls on trace element substitution in magnetite [62]), or among co-existing minerals formed at equilibrium (e.g., coexisting sphalerite-galena-chalcopyrite assemblages [59]) can be developed. Such constraints have been complemented by empirical studies showing how lattice-scale controls aid incorporation of a broader range of trace elements, including those overlooked in broader approaches. Examples include the observation of superstructuring in hematite allowing incorporation of $(\mathrm{U}+\mathrm{Pb}+\mathrm{W}+\mathrm{Mo})[7]$, the incorporation of $\mathrm{Au}$ into bismuth chalcogenides [63], and inter-lamellar enrichment of chalcophile elements in molybdenite [64].

Table 2. Selected studies that have used LA-ICP-MS to address the trace element geochemistry of common sulphides, iron-oxides, rock-forming silicates and accessory minerals.

\begin{tabular}{|c|c|}
\hline Minerals & Reference(s) \\
\hline Sphalerite & $\begin{array}{l}\text { Cook et al. (2009) [61], Ye et al. (2011) [65], Cook et al. (2012) [66], } \\
\text { Murakami and Ishihara (2013) [67], Lockington et al. (2014) [68], } \\
\text { Belissont et al. (2014) [69], Cook et al. (2015) [70] }\end{array}$ \\
\hline Chalcopyrite & $\begin{array}{l}\text { Butler and Nesbitt (1999) [71], Wohlgemuth-Ueberwasser et al. } \\
\text { (2015) [72], George et al. (in review) [73] }\end{array}$ \\
\hline Bornite, chalcocite-group & Cook et al. (2011) [74] \\
\hline Galena & George et al. (2015) [75] \\
\hline Pyrite & $\begin{array}{l}\text { Large et al. (2007) [76], Cook et al. (2009) [47], Large et al. } \\
\text { (2009) [77], Winderbaum et al. (2012) [78], Ingham et al. (2014) [79], } \\
\text { Large et al. (2014) [80] }\end{array}$ \\
\hline Arsenopyrite & $\begin{array}{l}\text { Morey et al. (2008) [81], Sung et al. (2008) [46], Cook et al. } \\
\text { (2013) [48], Lawley et al. (2015) [82] }\end{array}$ \\
\hline Enargite & Deyell and Hedenquist (2011) [83] \\
\hline Molybdenite & Ciobanu et al. (2013) [64] \\
\hline $\begin{array}{l}\text { Pyrrhotite-pentlandite- (pyrite, Ni-arsenides) } \\
\text { in magmatic ores, including PGE deposits }\end{array}$ & Barnes et al. (2008) [84]; see also Table 3 \\
\hline Bismuth chalcogenides and sulphosalts & Ciobanu et al. (2009) [63] \\
\hline Hematite & Ciobanu et al. (2013) [7] \\
\hline Magnetite & Nadoll et al. (2014) [62], Dare et al. (2014) [85] \\
\hline Chromite & Pagé and Barnes (2009) [86] \\
\hline Gahnite & O'Brien et al. (2015) [87] \\
\hline Scheelite, wolframite, ferberite & $\begin{array}{l}\text { Goldmann et al. (2013) [88], Song et al. (2014) [89], Hazarika et al. } \\
\text { (2016) [90], Raju et al. (2016) [91] }\end{array}$ \\
\hline Xenotime, florencite & Cook et al. (2013) [92] \\
\hline $\begin{array}{l}\text { (Calcic, skarn) garnet and other skarn } \\
\text { calc-silicates (pyroxenes, clinozoisite, etc.) }\end{array}$ & $\begin{array}{l}\text { Smith et al. (2004) [93], Gaspar et al. (2008) [94], Ismail et al. } \\
\text { (2014) [53], Xu et al. (2016) [95] }\end{array}$ \\
\hline Feldspars & Kontonikas-Charos et al. (2014) [96] \\
\hline Rutile and titanite & Smith et al. (2009) [97], Ismail et al. (2014) [53], Fu et al. (2016) [98] \\
\hline Apatite & Ismail et al. (2014) [53], He et al. (2016) [99], She et al. (2016) [100] \\
\hline Fluorite & Gagnon et al. (2003) [101] \\
\hline
\end{tabular}

Empirical studies aimed at understanding the fundamental ability of minerals to incorporate measurable concentrations of trace elements, the controls on trace element distributions, and partitioning behavior in multi-mineral assemblages underpin the three main applications of LA-ICP-MS trace element analysis. These are: (1) Trace element distributions in common, widely distributed phases such as pyrite, or extended mineral families, such as spinels or garnets, where variation in absolute trace 
element concentrations, or their relative distributions can be valuable for understanding the nature and sequence of ore-forming processes; (2) trace element distributions in minerals that display spatial relationships at the regional or deposit scales and which can be used in a vector approach in mineral exploration; and (3) microanalysis of minerals that can potentially host elements of economic interest, or elements which are deleterious to various metallurgical processes, and where an understanding of the distribution of a particular element or group of elements is of interest in element deportment and geometallurgical studies. Each of these will be highlighted in the following sections.

\section{LA-ICP-MS Analysis in Ore Petrogenesis}

Trace element data for minerals is increasingly used to support models for ore genesis. Recognition of distinct trace element signatures can assist with tracking sequences of crystallization and stages of mineralization, sources of metals, evolution of ore-forming fluids over time, and overprinting during superimposed geological events. Using examples from the recent literature, we focus here on four groups of deposits for which trace element studies are advancing the understanding of ore-forming processes.

\subsection{Orthomagmatic Ore Deposits}

A substantial volume of literature exists on the distribution and partitioning behaviors of trace elements among sulphides and co-existing oxides and silicates in orthomagmatic ore systems. In many ways, such systems are far better understood than their hydrothermal counterparts, assisted to some degree by temperature constraints from melt compositions and predictable, relatively closed-system behavior of mineral assemblages in magmatic environments. This work has been driven by the desire to understand controls on the partitioning behavior of the platinum-group elements (PGE) and shows a surprising range of behaviors from system to system. Trace element distribution patterns have, in turn, delivered valuable evidence in support of genetic models, and the sequence of crystallization. Representative advances in the field are summarized in Table 3.

Table 3. Selected examples of LA-ICP-MS studies of trace element distribution in minerals from orthomagmatic ore systems.

\begin{tabular}{|c|c|c|c|}
\hline Reference & $\begin{array}{l}\text { Mineral(s) } \\
\text { Analyzed }\end{array}$ & $\begin{array}{c}\text { Deposit(s) } \\
\text { Studied }\end{array}$ & Significant Findings \\
\hline $\begin{array}{l}\text { Barnes et al. } \\
\text { (2008) [84] }\end{array}$ & $\begin{array}{l}\text { Pentlandite, } \\
\text { chalcopyrite, } \\
\text { cubanite, } \\
\text { pyrrhotite }\end{array}$ & $\begin{array}{l}\text { Compilation of } \\
\text { data from } \\
\text { various Pt-rich } \\
\text { ore deposits } \\
\text { (Noril'sk, Great } \\
\text { Dyke, Bushveld } \\
\text { and others }\end{array}$ & $\begin{array}{l}\text { Siderophile and chalcophile element distributions in pentlandite, } \\
\text { chalcopyrite and pyrrhotite from platinum-rich ore deposits are } \\
\text { compared. Re, Os, Ir, Ru and Rh are concentrated in both } \\
\text { pentlandite and pyrrhotite. Pentlandite also concentrates } \mathrm{Ni}, \mathrm{Co} \\
\text { and } \mathrm{Pd} . \mathrm{Cu}, \mathrm{Zn}, \mathrm{Cd} \text { and } \mathrm{Ag} \text { are concentrated in chalcopyrite or } \\
\text { cubanite. } \mathrm{Au} \text { and } \mathrm{Pt} \text { do not preferentially concentrate in any } \\
\text { particular BMS, with very little of these elements located in BMS. } \\
\text { Significant differences in trace element distribution between ore } \\
\text { systems can be related to temperature evolution, abundance of } \\
\text { sulphides and availability of other minor elements (As, Te, Bi, etc.). }\end{array}$ \\
\hline $\begin{array}{l}\text { Dare et al. } \\
(2010) \text { [102] }\end{array}$ & $\begin{array}{l}\text { BMS } \\
\text { (pyrrhotite, } \\
\text { pentlandite, } \\
\text { chalcopyrite, } \\
\text { pyrite) }\end{array}$ & $\begin{array}{l}\text { Creighton } \\
\text { Ni-Cu-PGE } \\
\text { sulphide } \\
\text { deposit, } \\
\text { Sudbury, } \\
\text { Canada }\end{array}$ & $\begin{array}{l}\text { BMS host all Co and Se, a significant proportion }(40 \%-90 \%) \text { of } \mathrm{Os} \text {, } \\
\mathrm{Pd}, \mathrm{Ru}, \mathrm{Cd}, \mathrm{Sn} \text {, and } \mathrm{Zn} \text {, but very little (<35\%) of the } \mathrm{Ag}, \mathrm{Au}, \mathrm{Bi}, \mathrm{Ir} \text {, } \\
\mathrm{Mo}, \mathrm{Pb}, \mathrm{Pt}, \mathrm{Rh}, \mathrm{Re}, \mathrm{Sb} \text { and Te. Os and } \mathrm{Ru} \text { are concentrated in equal } \\
\text { proportions in pyrrhotite, pentlandite, and pyrite. Cobalt and } \mathrm{Pd} \\
(\sim 1 \mathrm{ppm}) \text { are concentrated in pentlandite. } \mathrm{Ag}, \mathrm{Cd}, \mathrm{Sn}, \mathrm{Zn} \text {, and in } \\
\text { rare cases } \mathrm{Au} \text { and Te, are concentrated in chalcopyrite. Se is present } \\
\text { in equal proportions in all three BMS. Ir Rh, and Pt are present in } \\
\text { euhedrally zoned PGE sulph-arsenides. Enrichment of Os, } \mathrm{Ru}, \mathrm{Ni} \text {, } \\
\text { and Co in pyrrhotite, pentlandite, and pyrite and } \mathrm{Ag}, \mathrm{Au}, \mathrm{Cd}, \mathrm{Sn}, \mathrm{Te} \\
\text { and } \mathrm{Zn} \text { in chalcopyrite explained by fractional crystallization of } \\
\text { MSS from sulphide liquid followed by sulphide exsolution. } \\
\text { The bulk of Pd in pentlandite cannot be explained by sulphide } \\
\text { fractionation alone because Pd should have partitioned into } \\
\text { residual Cu-rich liquid and be in chalcopyrite or in PGM around } \\
\text { chalco-pyrite. The variation of Pd among different pentlandite } \\
\text { textures provides evidence that Pd diffuses into pentlandite during } \\
\text { exsolution from MSS. }\end{array}$ \\
\hline
\end{tabular}


Table 3. Cont.

\begin{tabular}{|c|c|c|c|}
\hline Reference & $\begin{array}{l}\text { Mineral(s) } \\
\text { Analyzed }\end{array}$ & $\begin{array}{l}\text { Deposit(s) } \\
\text { Studied }\end{array}$ & Significant Findings \\
\hline $\begin{array}{l}\text { Dare et al. } \\
\text { (2011) [103] }\end{array}$ & $\begin{array}{l}\text { Pyrrhotite, } \\
\text { pentlandite, } \\
\text { chalcopyrite, } \\
\text { pyrite }\end{array}$ & $\begin{array}{l}\text { McCreedy East, } \\
\text { Sudbury, } \\
\text { Canada }\end{array}$ & $\begin{array}{l}\text { Os, Ir, Ru, Rh (IPGE), and Re concentrated in pyrrhotite, } \\
\text { pentlandite, and pyrite. Pd present in pentlandite. Some Pt noted in } \\
\text { oscillatory-zoned pyrite. }\end{array}$ \\
\hline $\begin{array}{l}\text { Dare et al. } \\
\text { (2012) [104] }\end{array}$ & Magnetite & $\begin{array}{l}\text { Sudbury, } \\
\text { Canada }\end{array}$ & $\begin{array}{l}\text { Fe-oxide geochemistry a sensitive petrogenetic indicator for the } \\
\text { degree of fractionation of the sulphide liquid. In sulphide-bearing } \\
\text { liquids, lithophile elements are compatible into Fe-oxide. } \\
\text { The concentrations of these elements are highest in the } \\
\text { early-forming titanomagnetite, which crystallized with Fe-rich MSS. } \\
\text { Late-forming magnetite, which crystallized from residual Cu-rich } \\
\text { liquid, is depleted in these elements. Behavior of chalcophile } \\
\text { elements in magnetite largely controlled by the crystallization of } \\
\text { sulphides. Local trace element redistribution occurs at subsolidus } \\
\text { temperatures (ilmenite ex-solution from titanomagnetite, Al-spinel } \\
\text { exsolution from magnetite). }\end{array}$ \\
\hline $\begin{array}{l}\text { Dare et al. } \\
\text { (2014a) [85] }\end{array}$ & Magnetite & $\begin{array}{l}\text { Compilation of } \\
\text { data from } \\
\text { magmatic and } \\
\text { hydrothermal } \\
\text { environments }\end{array}$ & $\begin{array}{l}\text { Discussion of trace element partitioning behaviour between } \\
\text { magnetite, melt/fluid, and co-crystallizing phases. Trace elements } \\
\text { aid discrimination of magnetite formed in different environments, } \\
\text { with applications in petrogenetic and provenance studies. }\end{array}$ \\
\hline $\begin{array}{l}\text { Dare et al. } \\
(2014 b)[105]\end{array}$ & $\begin{array}{l}\text { BMS, also } \\
\text { sphalerite and } \\
\text { galena }\end{array}$ & $\begin{array}{l}\text { McCreedy East, } \\
\text { Sudbury, ON, } \\
\text { Canada }\end{array}$ & $\begin{array}{l}\text { Distribution of PGE and trace elements in different sulphides } \\
\text { reported and comprehensive genetic model presented. }\end{array}$ \\
\hline $\begin{array}{l}\text { Duran et al. } \\
\text { (2015) [106] }\end{array}$ & Pyrite & $\begin{array}{l}\text { Lac des Iles Pd } \\
\text { deposits, ON, } \\
\text { Canada }\end{array}$ & $\begin{array}{l}\text { Atypical deposits in which pyrite contains } \mathrm{Os}, \mathrm{Ir}, \mathrm{Ru} \text { and } \mathrm{Rh} \\
\text { (also present in pyrrhotite and pentlandite), possibly redistributed } \\
\text { during cooling. Pyrite is zoned: IPGE- } \mathrm{Rh} \text { and As towards pyrite } \\
\text { cores, Co and Se towards the rims. } \mathrm{Pb}, \mathrm{Bi} \text { and } \mathrm{Ag} \text { present in thin } \\
\text { overgrowths on pyrite margins (also some } \mathrm{Pt}, \mathrm{Te} \text { and } \mathrm{Sn} \text { ). }\end{array}$ \\
\hline $\begin{array}{l}\text { Godel et al. } \\
(2007)[107]\end{array}$ & $\begin{array}{l}\text { BMS } \\
\text { (pyrrhotite, } \\
\text { pentlandite, } \\
\text { chalcopyrite) }\end{array}$ & $\begin{array}{l}\text { Merensky Reef, } \\
\text { Bushveld } \\
\text { Complex }\end{array}$ & $\begin{array}{l}\sim 65 \% \text { up to } ~ 85 \% \text { of PGE hosted by PGM. Lesser amounts of PGE in } \\
\text { solid solution within BMS. Pentlandite is the principal BMS host of } \\
\text { all PGE, except Pt (preferentially enriched in Pd, Rh and Co). } \\
\text { Pyrrhotite contains, Rh, Os, Ir and Ru, but excludes both Pt and Pd. } \\
\text { Chalcopyrite contains very little PGE. The PGE content in the BMS } \\
\text { varies only slightly as a function of the stratigraphy (twice as much } \\
\text { PGE in BMS from chromitites compared to silicate rocks). }\end{array}$ \\
\hline $\begin{array}{l}\text { Godel and } \\
\text { Barnes (2008) } \\
\text { [108] }\end{array}$ & $\begin{array}{l}\text { BMS } \\
\text { (pyrrhotite, } \\
\text { pentlandite, } \\
\text { chalcopyrite) }\end{array}$ & $\begin{array}{l}\text { J-M Reef, } \\
\text { Stillwater } \\
\text { Complex }\end{array}$ & $\begin{array}{l}\text { Pentlandite main host for Pd. Pt occurs almost exclusively found as } \\
\text { PGM and do not partition into BMS. Other PGE present in BMS. } \\
\text { Highest PGE noted in samples containing secondary magnetite. } \\
\text { Pd precipitated as an alloy, later diffusing into pentlandite. }\end{array}$ \\
\hline $\begin{array}{l}\text { Holwell et al. } \\
\text { (2015) [109] }\end{array}$ & $\begin{array}{l}\text { sulphide } \\
\text { microdroplets }\end{array}$ & $\begin{array}{l}\text { Platinova Reef, } \\
\text { Skaergaard E } \\
\text { Greenland }\end{array}$ & $\begin{array}{l}\text { Extreme trace element enrichment in sulphide droplets in } \\
\text { closed-system layered intrusions, forming unusual } \\
\text { low-sulphide deposits. }\end{array}$ \\
\hline $\begin{array}{l}\text { Piña et al. } \\
\text { (2013) [110] }\end{array}$ & $\begin{array}{l}\text { Maucherite, } \\
\text { pyrrhotite, } \\
\text { pentlandite, } \\
\text { chalcopyrite }\end{array}$ & $\begin{array}{l}\text { Beni Bousera, } \\
\text { Morocco }\end{array}$ & $\begin{array}{l}\text { Partition coefficients for PGE, } \mathrm{Au}, \mathrm{Re}, \mathrm{Ag}, \mathrm{Se}, \mathrm{Bi}, \mathrm{Te}, \text { and } \mathrm{Sb} \text {, } \\
\text { between arsenide and sulphide phases estimated. Maucherite } \\
\text { strongly enriched in all chalcophile elements, except Se, relative to } \\
\text { sulphide minerals. Results highlight the strong affinity of PGE for } \\
\text { arsenide phases and the importance of these phases as potential } \\
\text { carriers of PGE. }\end{array}$ \\
\hline $\begin{array}{l}\text { Piña et al. } \\
\text { (2015) [111] }\end{array}$ & $\begin{array}{l}\text { Ni-arsenides } \\
\text { (nickeline, } \\
\text { maucherite, } \\
\text { löllingite) }\end{array}$ & $\begin{array}{l}\text { Serranía de } \\
\text { Ronda, Málaga, } \\
\text { Spain }\end{array}$ & $\begin{array}{l}\text { PGE, Au, Ag, Se, Sb, Bi and Te contents of arsenide and sulphide } \\
\text { assemblages determined. Arsenides enriched in all PGE, but } \\
\text { especially in Ir, Rh and Pt. Se and Ag partition preferentially into } \\
\text { the sulphide assemblage. }\end{array}$ \\
\hline $\begin{array}{l}\text { Piña et al. } \\
\text { (2016) [112] }\end{array}$ & Pyrite & $\begin{array}{l}\text { Main Sulphide } \\
\text { Zone, Great } \\
\text { Dyke, } \\
\text { Zimbabwe }\end{array}$ & $\begin{array}{l}\text { PGE and other trace element contents in pyrite reported from } \\
\text { several mines. Two types of pyrite differentiated. Py } 1 \text { is PGE rich } \\
\text { (higher Os, Ir, Ru, Rh, and Pt contents than the associated } \\
\text { pyrrhotite, pentlandite, and chalcopyrite); Py2 has low PGE } \\
\text { contents. Py1 inferred to have formed by late, low temperature } \\
\left(<300^{\circ} \mathrm{C}\right) \text { decomposition of residual Ni-rich mss; Py2 suggested to } \\
\text { have formed by replacement of pyrrhotite and pentlandite caused } \\
\text { by late magmatic/hydrothermal fluids. }\end{array}$ \\
\hline
\end{tabular}


Table 3. Cont.

\begin{tabular}{clll}
\hline Reference & $\begin{array}{c}\text { Mineral(s) } \\
\text { Analyzed }\end{array}$ & $\begin{array}{c}\text { Deposit(s) } \\
\text { Studied }\end{array}$ & \multicolumn{1}{c}{ Significant Findings } \\
\hline $\begin{array}{l}\text { Duran et al. } \\
\text { (2016) [113] }\end{array}$ & $\begin{array}{l}\text { Sulphides, } \\
\text { Fe-Ti-oxides }\end{array}$ & $\begin{array}{l}\text { Lac des Iles Pd } \\
\text { deposits, ON, } \\
\text { Canada }\end{array}$ & $\begin{array}{l}\text { Trace element concentration data for pyrrhotite, pentlandite and } \\
\text { chalcopyrite and co-existing Fe-Ti oxides (magnetite and ilmenite) } \\
\text { The study shows how the trace element composition of sulphides } \\
\text { can vary as a function of the degree of fractionation of the parental } \\
\text { silicate magma. Findings carry strong implications for the } \\
\text { petrogenesis of orthomagmatic deposits. }\end{array}$ \\
\hline
\end{tabular}

Abbreviations: BMS—base metal sulphides; PGE—platinum group elements; IPGE—intermediate platinum group elements $(\mathrm{Os}+\mathrm{Ir}+\mathrm{Ru})$; PGM-platinum group minerals; MSS-monosulphide solid solution.

\subsection{Skarn Formation}

Calcic skarns comprise a number of gangue minerals (garnet from andradite-grossular series, pyroxene from the diopside-hedenbergite-johanssonite series, clinozoizite from the epidote supergroup and abundant accessories), which are widely distributed across skarn deposits. These minerals are known to feature significant concentrations of substituting trace elements, notably REY, opening new avenues to explore skarn evolution in space and time. Despite this, there have been relatively few published studies that specifically target trace element incorporation and partitioning in skarn minerals by LA-ICP-MS. Smith et al. (2004) [93] described garnets from the Beinn and Dubhaich contact aureoles, Scotland, which were enriched in HREE or LREE depending upon their grossularor andradite-rich composition. High U contents (up to several hundred ppm) were also measured in such garnets. The measured REY-fractionated trends across crystal zoning in garnet were numerically modeled with respect to changes in salinity [93]. Evolving REE fractionation trends could be used as a tool to understand the evolution of metasomatic fluids. Gaspar et al. (2008) [94] studied factors that control REE incorporation into garnets and showed that evolving REE fractionation trends could be used as a tool to understand the temporal evolution of metasomatic fluids during skarn formation.

A holistic approach was taken to address the genesis of the Hillside Cu skarn-IOCG prospect, South Australia [53]. Trace element datasets covered calcic garnet, diopside, clinozoisite and accessory minerals as well as magmatic and early-hydrothermal feldspars. It was shown that prograde and retrograde assemblages can be differentiated by distinct chondrite-normalised REY fractionation trends, paralleled by changes from proximal to distal position within the deposit. Moreover, application of Zr-in-titanite geothermometry revealed the thermal evolution of the skarn from the magmatic-hydrothermal transition $\left(\sim 700^{\circ} \mathrm{C}\right)$ through the main (prograde) stage of skarn formation associated with mineralization down to late, retrograde fluids $\left(\sim 300^{\circ} \mathrm{C}\right)$.

In a second prospect from the same terrane (the Groundhog copper prospect, Punt Hill district), Nikolakopoulos (2013) [114] documented garnet compositional data in strongly retrogressive calcic skarn assemblages, demonstrating that a number of mineralogical and geochemical features are common to IOCG systems within the Olympic Cu-Au Province. As at Hillside, distinct textural categories of garnet, each reflecting stages in the evolution of the skarn system, are recognized. Fe-rich prograde andradite is oscillatory-zoned, with high $\mathrm{W}$ and As, relatively low $\Sigma R E Y$, and low HREE/LREE. Later, retrograde garnets, assigned to the waning stages of the hydrothermal system, are Al-rich, have $\Sigma$ REY concentrations an order of magnitude higher, high HREE/LREE, and high concentrations of incompatible and high field strength elements. Marked enrichment in $\mathrm{Cr}$ defines the garnet rim.

In a study on the Zhibula Cu skarn deposit, Tibet, Xu et al. (in press) [95] have shown that garnet colors are largely defined by trace element concentrations. Chondrite-normalized REY fractionation trends in garnet can be correlated with the evolving salinity of ore-forming fluids. Garnets from this deposit are enriched in an extraordinary range of trace elements less commonly reported for garnet, including W, Sn, and As, but also Mo (as high as $730 \mathrm{ppm}$ ). Garnet compositions support a genetic connection between the Zhibula skarn and the Qulong porphyry deposit located $2 \mathrm{~km}$ to the 
north. Trace element signatures in Zhibula garnets demonstrate the usefulness of this type of approach (see also [108]) to establish genetic links between skarn and porphyry systems.

An important point here is that although garnet, pyroxene and other minerals in calcic skarns, are characterized by trace element signatures that can be used to constrain skarn zonation and evolution in space and time, neither patterns nor trace element substitution mechanisms in garnet are necessarily identical from case to case. This has precluded development of generalized trace element models for skarn systems. These studies have also highlighted that the skarn minerals, rather than sulphides, can be significant sinks for minor metals of potential economic interest. Examples include the extraordinary enrichment of Ga in clinozosite [53], and of Mo, W and Sn is some skarn garnets [95,115], or magnetite [116].

\subsection{Iron-Oxide-Apatite (IOA) and Iron-Oxide Copper Gold (IOCG) Deposits}

IOA and IOCG deposit types belong to a broad spectrum of hydrothermal ore deposits with distinct characteristics underpinned by a range of common features [117]. Among these are the presence of abundant Fe-oxides (hematite and magnetite), the common phosphate, apatite, other accessory minerals such as rutile and titanite, and not least feldspar of either magmatic or hydrothermal origin. Such minerals are distributed, in varying proportions, within IOA and IOCG systems, and in each, these trace minerals have great potential for fingerprinting the magmatic to hydrothermal transition and the different origins of the protoliths to the host rocks. In IOCG systems, trace element analysis of Fe-oxides, apatite and other accessories allows recognition of distinct mineral generations formed throughout the hydrothermal lifespan of the system. Here we present existing data related to IOCG systems, including some enigmatic deposits whose affiliation to this clan is debated (e.g., Bayan Obo, El Laco, see below). What follows is a selection of examples from the recent literature intended to highlight various perspectives and the interpretation of LA-ICP-MS datasets obtained on different minerals, and in different deposits or provinces.

In a pioneering study, Smith et al. (2009) [97] used the REE trends in apatite and rutile/titanite from the Kiruna Fe-deposit, Sweden, to model deposit evolution. A number of recent publications have addressed the genesis of iron-oxide-apatite (IOA) deposits based on the trace element geochemistry of Fe-oxides and/or apatite.

Huang et al. (2015) [118] investigated magnetite and hematite compositions from banded, disseminated and massive Fe ores in the Bayan Obo Fe-REE-Nb deposit, Northern China, in an effort to understand the genesis of this world-class REE deposit. Magnetite and hematite show similar REE patterns and trace element signatures, indicating a common origin. Two stages of REE mineralization and multiple sources of Fe and REE are indicated. The authors propose a model involving sedimentary carbonates and subsequent metasomatism by REE-rich hydrothermal fluids. Magnetite chemistry has proven critical for understanding the transition from magmatic to hydrothermal conditions in Kiruna-type iron oxide-apatite (IOA) deposits [119].

LA-ICP-MS analysis of trace elements in apatite have also been used to understand the genesis of nelsonites and other apatite-oxide-rich rocks in magmatic environments $[99,100]$. Based on a study of rocks from the Sept-Îles Intrusive Suite, Canada, Tollari et al. (2008) [120] were able to substantiate a crystal accumulation model in which the nelsonites could have formed as dyke-like bodies.

Chen et al. (2015) [121] investigated magnetite in the Khetri copper belt in Rajasthan Province, NW India, revealing that ore-forming conditions were controlled mainly by fluid compositions and/or $f \mathrm{O}_{2}$. Factors such as temperature, fluid-rock interaction and co-precipitating minerals were found to play negligible roles in controlling composition.

Oscillatory and sectorial zoning patterns were mapped in both hematite and magnetite from the Olympic Dam IOCG deposit, South Australia [7,122]. Such patterns involve variation in U, Pb, W, Sn, Mo and REY, elements that we group broadly as 'granitophile'. Moreover, grain-scale variation in As and $\mathrm{Sb}$ concentrations within hematite have also been shown [122]. The same study showed significant differences in hematite composition between the deepest and shallower parts of the Olympic Dam 
deposit in terms of trace element signatures and REY content. Such trends have the potential to underpin space-time evolution models, if understood in the context of the host rocks and regionaland mine-scale alteration patterns at Olympic Dam, a deposit well-known for mineralogically- and geochemically-defined zonation patterns [123].

There is, however, one important problem when making easy generalization of LA-ICP-MS datasets for Fe-oxides in IOCG deposits-the fact that they are probably the only minerals that are continuously generated and reworked through cycles of brecciation. Such cycles will induce trace element heterogeneity associated with dissolution, recrystallization, pseudomorphic replacement and release of trace elements that will overprint pre-existing grains at the scale of the polished block. We demonstrate this variation by two contrasting examples of hematite from high-grade bornite ore at Olympic $\mathrm{Dam}$, which have been dated by hematite $\mathrm{Pb}-\mathrm{Pb}$ geochronology [7]. The examples differ from one another in terms of morphology, internal textures and trace element distributions (Figures 5 and 6). They do, however, represent the main categories of hematite within such ores.

The type of hematite containing high concentrations of granitophile elements occurs as acicular grains and radial aggregates that display zoning of individual lamella on the BSE images (Figure 5a,b). The same lamellae also show areas of abundant porosity and mineral inclusions (Figure $5 \mathrm{c}$ ). The LA-ICP-MS map (Figure 5d) shows that the bright areas on BSE images correlates with high-U, $\mathrm{Pb}$, Mo and $\mathrm{W}$, whereas the same areas show depletion in HFSE $(\mathrm{Nb}, \mathrm{V}, \mathrm{Ti})$, and mild increase of these elements in the porous domains. The core of the aggregates shows also an increase in LREE (Ce as a proxy).

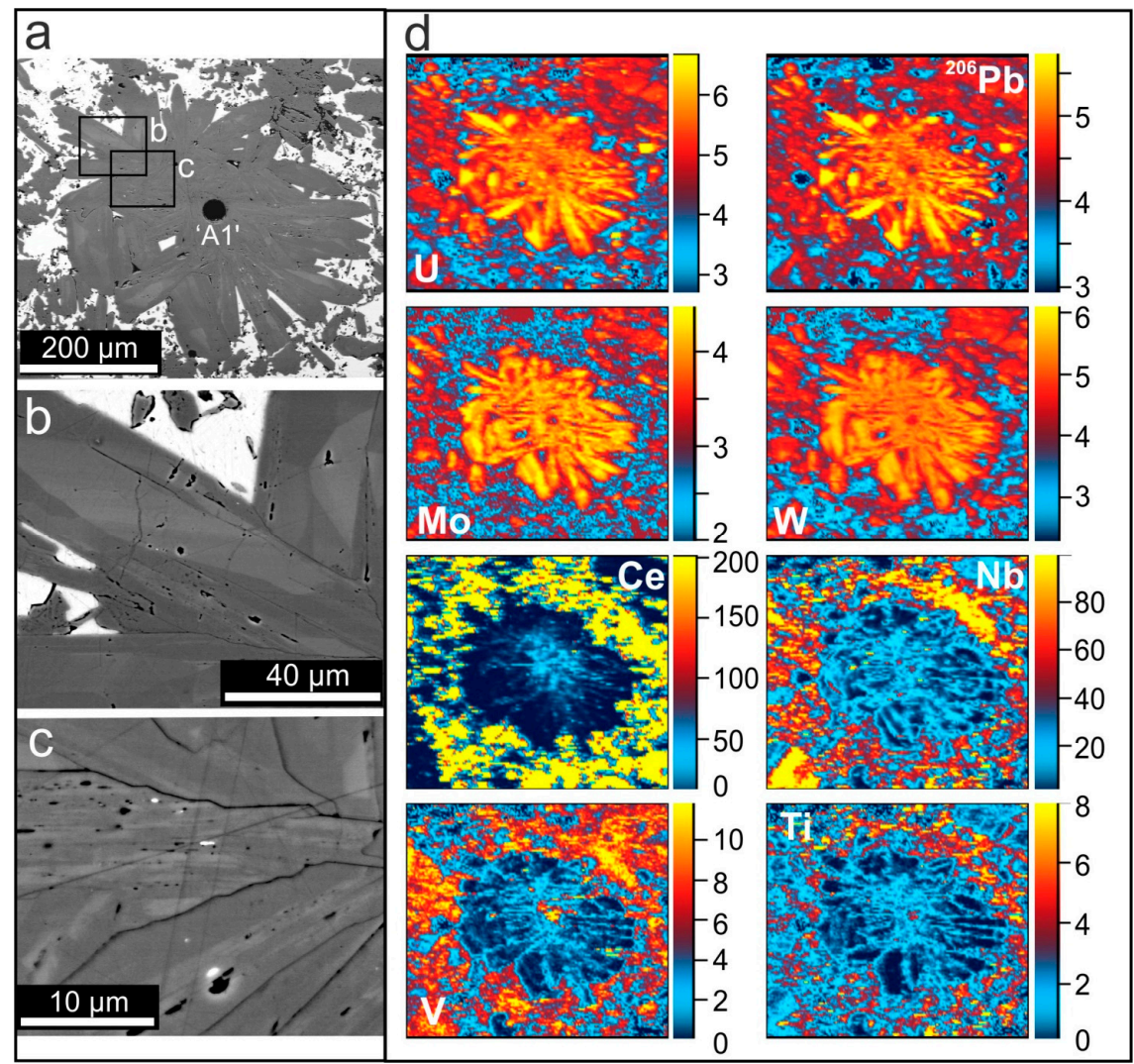

Figure 5. BSE images (a)-(c) showing textural details of a radial aggregate of hematite hosted in bornite (white in $(a, b))$ from Olympic Dam. Note the zoning and porosity within individual lamellae depicted on the BSE images in (b) and (c), respectively. (d) LA-ICP-MS element maps of the hematite aggregate shown in (a); note good correspondence between textures on BSE images and specific groups of elements, i.e., zoning with respect of $\mathrm{U}, \mathrm{Pb}, \mathrm{Mo}$ and $\mathrm{W}$ (middle parts of lamellae), and enrichment in HFSE in the porous, marginal parts of the same lamellae. Scales in counts-per-second $\left(\times 10^{3}\right.$ except for Ce and $\mathrm{Nb}$ ). Measured isotopes: ${ }^{238} \mathrm{U},{ }^{206} \mathrm{~Pb},{ }^{95} \mathrm{Mo},{ }^{182} \mathrm{~W},{ }^{140} \mathrm{Ce},{ }^{93} \mathrm{Nb},{ }^{51} \mathrm{~V},{ }^{47} \mathrm{Ti}$. 
The second type (Figure 6) is illustrative of the abundant, coarser hematite grains that have been pseudomorphosed by fine-aggregates of hematite preserving the crystal shape, albeit with some grain rounding (Figure 6a). In detail, such hematite shows coarser, sub-micron inclusions of REE-minerals within areas of high porosity (Figure 6b,c). At the micron-scale, such porous areas show a 'channel'-like texture, which can be correlated with the element maps (Figure 6e). The maps show a correlation between the inclusions and the elements U, Y and Er (typical of coffinite-xenotime minerals), as well as an enrichment in $\mathrm{Al}$, and depletion in $\mathrm{W}$ and $\mathrm{V}$ within the channel areas shown in Figure $6 \mathrm{~d}$.

Although Fe-oxides in certain deposit types display characteristic geochemical signatures that underpin effective discrimination schemes and can be correlated with ore-forming processes [124], there is likely to be wide variability in any particular hydrothermal deposit, or among deposits of a specific type. This is particularly true for IOCG systems where there remains an inadequate understanding of how fluid/water chemistry and specific formation conditions impact on Fe-oxide compositions.

Controls on the diversity of trace element signatures derive from different fluid sources, participation of multiple host lithologies (granites, BIF, mafic rocks), and competition for trace elements with other minerals, including accessories and REE-minerals (and also skarn minerals if the protoliths are limestone).

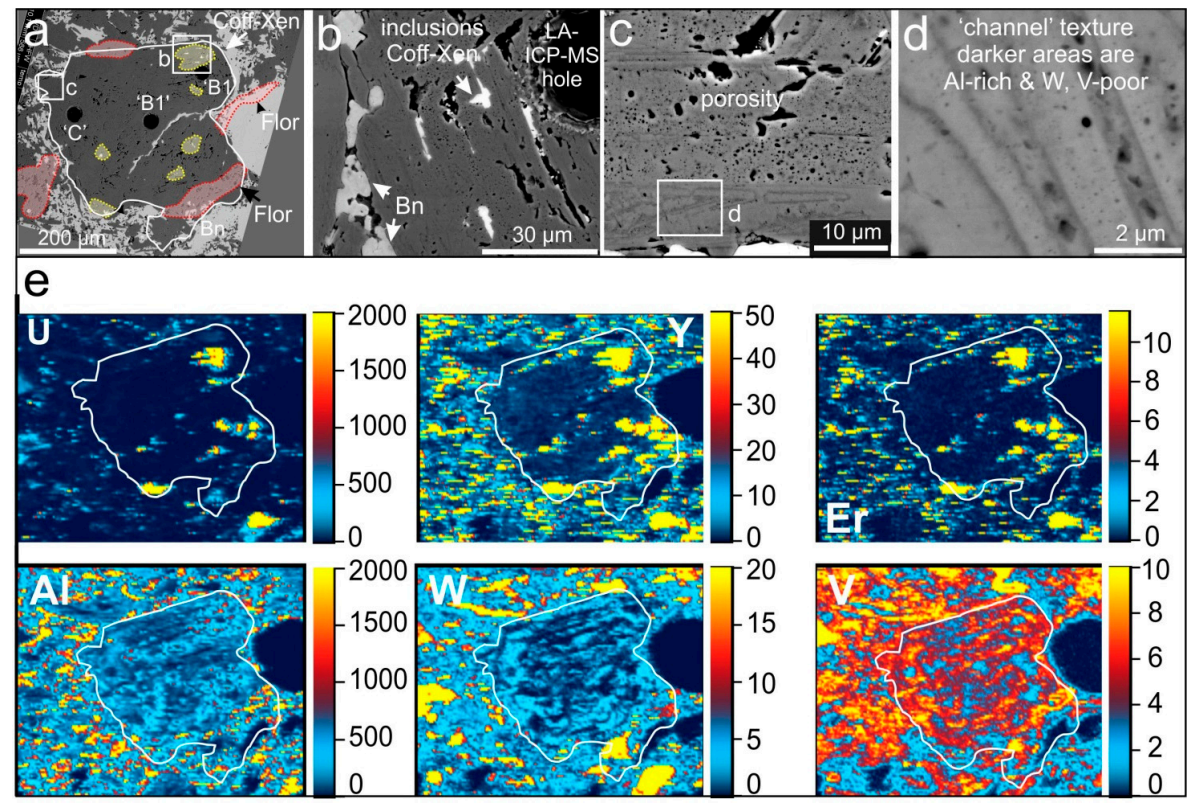

Figure 6. BSE images (a-d) showing the textures of coarser, sub-rounded grain of hematite from the same sample as in Figure 5 (aggregate of acicular lamellae). Note the presence of $\mu \mathrm{m}$ to sub- $\mu \mathrm{m}$ size REE-mineral inclusions $(\mathbf{a}, \mathbf{b})$, as well as the abundance of pores throughout most of the grain (c); (d) channel-like sub-texture shows a correlation between high concentrations of $\mathrm{Al}$ with low concentrations of $\mathrm{W}$ and V; (e) LA-ICP-MS element maps of reworked, hematite resulting in a depletion of granitophile and HFSE trace elements. Note the correlation between the maps for U, $\mathrm{Y}$ and Er, showing the presence of REE inclusions in $(\mathbf{a}, \mathbf{b})$, as well as the channel-like patterns on the $\mathrm{Al}, \mathrm{W}, \mathrm{V}$ maps correlating with the texture in (d) containing micron-scale inclusions of $\mathrm{U}$ - and REE-minerals, extensive porosity and chemically-defined channel textures. Concentration scales in counts-per-second $\left(\times 10^{3}\right)$. Measured isotopes: ${ }^{238} \mathrm{U},{ }^{89} \mathrm{Y},{ }^{166} \mathrm{Er},{ }^{27} \mathrm{Al},{ }^{182} \mathrm{~W},{ }^{51} \mathrm{~V}$.

Although excellent hosts for $\mathrm{Ba}, \mathrm{Sr}, \mathrm{Rb}, \mathrm{Cs}$, and others, plagioclase and potassium feldspars are not traditionally considered good sinks for transition metals and lanthanides. Despite relatively low absolute concentrations, the abundance of feldspars can, however, mean that they are the dominant carriers of petrogenetically valuable trace elements. Kontonikas-Charos et al. (2014) [96] have documented concentrations of as much as $200 \mathrm{ppm} \sum(\mathrm{REE}+\mathrm{Y})$ in feldspars from an albite-biotite schist from the Moonta-Wallaroo region, Yorke Peninsula, South Australia, associated with IOCG mineralization. Such concentrations can account for nearly all (REE $+\mathrm{Y})$ in whole-rock. Chondrite-normalized REY 
fractionation patterns for feldspars support the applicability of REE-fractionation trends in feldspars as geochemical tracers of regional-scale hydrothermal alteration haloes.

Apatite is a common magmatic accessory in the same intrusive rocks hosting the world-class Olympic Dam deposit and hydrothermal apatite is a locally abundant mineral throughout the altered and mineralized rocks. Krneta et al. (2016) [125] have evaluated whether changes in the morphology and chemistry (particularly REE and Y content) of apatite can be used to constrain the evolution of giant IOCG systems. At Olympic Dam, magmatic apatite commonly contains inclusion-rich cores and REY-enriched rims. The cores show a LREE-enriched chondrite-normalized fractionation trend with a strong negative Eu-anomaly. Apatite intimately associated with advanced hematite-sericite alteration and mineralization display convex, MREE-enriched patterns with a weak negative Eu-anomaly. This change in REY-partitioning behavior could be due to changes in the physiochemical character of the mineralizing fluid, or alternatively, may indicate crystallization of MREE-enriched apatite in the presence of LREE- and HREE-consuming minerals such as monazite, florencite and xenotime. These dynamics are important evidence for a change from early primitive low-grade pyrite-chalcopyrite mineralization to high-grade bornite mineralization reflected in apatite chemistry by a switch from LREE- to MREE-enriched REY-trends.

Trace element concentrations in magnetite have also been used to decipher the genesis of the enigmatic El Laco deposit, Chile [126]. El Laco magnetite was shown to have a trace element signature comparable with high-temperature hydrothermal magnetites like those in IOCG or porphyry-Cu systems, supporting a model of metasomatic replacement of andesitic lava flows, and not a magmatic origin from an effusive Fe oxide liquid.

\subsection{Trace Elements in Pyrite in Hydrothermal Ore Deposits}

Pyrite is the most common sulphide in a wide variety of hydrothermal ore deposits. As a refractory mineral that is stable up to relatively high temperatures, and which readily preserves trace element signatures, pyrite trace element geochemistry has proven useful for understanding the genesis of volcanogenic massive sulphides, black shale hosted deposits and others $[76,77,80,127,128]$.

Applying LA-ICP-MS trace element mapping of pyrite within the Carbon Leader Reef, Witwatersrand Basin, South Africa, Large et al. (2013) [129] showed that "a significant proportion" of pyrite and gold in the reef was derived, via large-scale flow of basinal fluids, from sedimentary rocks stratigraphically below the reef. This is valuable evidence in support of a hybrid hydrothermal-palaeoplacer genetic model for the world's largest gold resource.

Gregory et al. (2015) [130] conducted LA-ICP-MS trace element analysis of $>1400$ diagenetic and syngenetic pyrites from 45 carbonaceous shale and unconsolidated sulfidic sediment samples. Despite extensive and often inconsistent variation in trace element signatures, three main groups of trace elements identified from factor analysis revealed element groupings that carry genetic implications, including recognisable signatures indicative of input from fluids associated with mafic rocks.

Steadman et al. (2015) [131] examined pyrites from black shale units in the Kalgoorlie goldfield, Western Australia, and observed complex, though generally systematic patterns of compositional zonation. These data support a genetic model for this world-class metallogenic terrane involving inter-volcanic (syn)diagenetic pre-concentration of $\mathrm{Au}-\mathrm{Ag}$-Te-Hg-As in fine-grained, sulphidic, moderate- to deep-water sediments before formation of gold-(telluride) lodes.

Trace element characterization of pyrite has been used to reconstruct the hydrothermal evolution of Archean VMS in the Abitibi Belt, Canada [132]. Five pyrite types were identified, each of which could be correlated with a distinct stage in the evolution of the mineralizing system. Recrystallization causes some early signatures to be partially obliterated, with migration of some minor elements out of pyrite. A near-mine vectoring approach to exploration is proposed based on discriminant diagrams. In a further application of pyrite trace element geochemistry, Mills et al. (2016) [133] compared compositions of pyrite from three belts within the Jiaodong gold district, Eastern China. Significant differences in pyrite geochemistry were related to style of gold mineralization, allowing a model for the timing of gold introduction, geodynamic setting, and for remobilization of gold. 


\section{Trace Element Vector Approaches in Mineral Exploration}

Interest in using the trace element concentration in a specific mineral in a vectoring approach to mineral exploration stems from the fact that mineral compositions are more sensitive to changes associated with ore-forming processes than whole rock is. This is because the geochemical signatures of each mineral are governed by crystal structures and often-constrainable physical-chemical parameters. They are thus much less prone to averaging-out effects than is the case for whole-rock data. Successful application does depend, however, on the mineral concerned being abundant in a range of lithologies across a deposit and within the alteration envelope enclosing the deposit. A second consideration is that the variance (or 'noise') in the geochemical signal within a specific sample needs to be sufficiently low to be able to recognize trends which correlate with distance from mineralization. Several dozen recent studies have used LA-ICP-MS analysis of minerals (sulphides, oxides and in some cases, also silicates) to support a vectoring or indicator mineral approach. A selection of these is given in Table 4 . Testing will be required to determine whether each can be duplicated in analogous terranes elsewhere.

In the Punt Hill district of South Australia, it was suggested [114] that trace element distributions in texturally-distinct categories of garnet can be used as vectors to mineralization within defined structural corridors. Vectors are defined by $\Sigma$ REY- and W-concentrations in prograde and retrograde garnets. Understanding structures that define the direction of fluid flow is critical for application of such vectors, as is an adequate interpretation of trace element data in the contexts of textural and prograde-to-retrograde evolution of the system.

An important potential application of the approaches listed in Table 4 is that if these minerals are recovered from glacial deposits of unknown or uncertain setting, mineral compositions may indicate the presence of potential mineralization upstream, directly impacting on exploration strategies depending on the mineralization type identified.

Table 4. Selected examples of LA-ICP-MS studies of minerals as indicators of proximal and distal position, or supporting a vector approach in mineral exploration.

\begin{tabular}{|c|c|c|}
\hline Vector Mineral & Reference & Geochemical Signature and Comment(s) \\
\hline Magnetite & $\begin{array}{l}\text { Boutroy et al. } \\
\text { (2014) [134] }\end{array}$ & $\begin{array}{l}\text { Compilation of trace element compositions in magnetite from } \\
13 \text { major Ni-Cu-PGE deposits. Controls on magnetite composition } \\
\text { discussed. Discrimination diagrams introduced to distinguish } \\
\text { primary from secondary magnetite. Magnetite considered a useful } \\
\text { indicator mineral in exploration, particularly if used to detect } \\
\text { eroded Ni-Cu-PGE deposits in surficial sediments. }\end{array}$ \\
\hline $\begin{array}{l}\text { Ni-arsenides } \\
\text { (gersdorffite, } \\
\text { nickeline) }\end{array}$ & $\begin{array}{l}\text { Le Vaillant et al. } \\
\text { (2015) [135] }\end{array}$ & $\begin{array}{l}\text { Case study: Miitel komatiite-hosted nickel sulphide deposit, } \\
\text { Western Australia Elevated Pd and Pt associated with Ni and As } \\
\text { enrichment. Pd- and Pt-enriched trace arsenides in country rocks } \\
\text { considered a proximity indicator for Ni-sulphides in } \\
\text { hydrothermally altered terranes. }\end{array}$ \\
\hline Magnetite & $\begin{array}{l}\text { Acosta-Góngora et al. } \\
\text { (2015) [136] }\end{array}$ & $\begin{array}{l}\text { Major differences in the } \mathrm{V}, \mathrm{Ni}, \mathrm{Cr} \text {, and } \mathrm{Co} \text { concentrations within } \\
\text { magnetite are reported from the Paleoproterozoic Great Bear } \\
\text { magmatic zone. } \mathrm{Cr} / \mathrm{Co} \text { and } \mathrm{V} / \mathrm{Ni} \text { ratios are useful to distinguish } \\
\text { barren alteration from mineralization. The results highlight } \\
\text { potential use of magnetite as an indicator mineral in exploration for } \\
\text { IOCG deposits. }\end{array}$ \\
\hline Pyrite & $\begin{array}{l}\text { Belousov et al. } \\
\text { (2016) [137] }\end{array}$ & $\begin{array}{l}\text { Pyrite compositions from VHMS and orogenic Au deposits in the } \\
\text { Yilgarn Craton, Australia are distinct. The data are useful for } \\
\text { distinguishing signatures at the exploration stage and have valuable } \\
\text { implications for the deportment of precious metals in these ores. }\end{array}$ \\
\hline Magnetite & $\begin{array}{l}\text { Canil et al. } \\
\text { (2016) [138] }\end{array}$ & $\begin{array}{l}\text { Trace element compositions are reported from hydrothermal } \\
\text { magnetite in } 5 \text { porphyry } \mathrm{Cu}-\mathrm{Mo}-\mathrm{Au} \text { deposits and two skarns from } \\
\text { B.C., Canada. Compositions are found to vary with temperature, } \\
\text { redox potential, and the acidity of the ore-forming fluids. } \\
\text { Concentrations of } \mathrm{Mn}, \mathrm{Sn} \text { and Mo in hydrothermal magnetite are } \\
\text { shown to vary with fluid acidity. Variations in Ti, Al and V are } \\
\text { inferred to depend on temperature and } f \mathrm{O}_{2} \text {. }\end{array}$ \\
\hline
\end{tabular}


Table 4. Cont.

\begin{tabular}{|c|c|c|}
\hline Vector Mineral & Reference & Geochemical Signature and Comment(s) \\
\hline Gahnite & $\begin{array}{l}\text { O'Brien et al. } \\
(2015)[87]\end{array}$ & $\begin{array}{l}\text { Major and trace element data for gahnite in the Broken Hill domain, } \\
\text { N.S.W., Australia is reported. Gahnite chemistry may be used to } \\
\text { distinguish prospective exploration targets from non-prospective } \\
\text { occurrences. Principal component analysis and variation of } \mathrm{Zn} / \mathrm{Fe} \\
\text { vs. } \mathrm{Ni}+\mathrm{Cr}+\mathrm{V} \text { distinguishes gahnite in the Broken Hill deposit } \\
\text { from that associated with sulphide-poor mineralization and barren } \\
\text { rocks. Gahnite is proposed as an exploration guide to high-grade } \\
\text { ore in analogous metamorphosed terranes. }\end{array}$ \\
\hline Magnetite & $\begin{array}{l}\text { Nadoll et al. } \\
\text { (2012) [139] }\end{array}$ & $\begin{array}{l}\text { Magnetite compositions from different geological settings in } \\
\text { western Montana and northern Idaho are compared. } \\
\text { Subtle differences are correlated with formation temperatures. } \\
\text { Factor analysis is used to discriminate genetic types of magnetite. } \\
\text { Magnetite is thus proposed as a useful discriminator and pathfinder } \\
\text { for hydrothermal deposits. }\end{array}$ \\
\hline Amphibole & $\begin{array}{l}\text { Hanley and Bray } \\
\text { (2009) [140] }\end{array}$ & $\begin{array}{l}\text { Elevated } \mathrm{Ni}, \mathrm{Cu} \text { and } \mathrm{Sn} \text { in amphiboles are noted within } 10 \text { to } 20 \mathrm{~m} \\
\text { from sulphide veins at Sudbury, ON, Canada. The mineral is } \\
\text { suggested to be a valuable proximity indicator for hidden } \\
\text { footwall-style sulphide deposits. }\end{array}$ \\
\hline Biotite & $\begin{array}{l}\text { Warren et al. } \\
\text { (2015) [141] }\end{array}$ & $\begin{array}{l}\text { The } \mathrm{Ni}, \mathrm{Cr} \text {, and } \mathrm{Cu} \text { contents of biotite vary as a function of } \\
\text { proximity to mineralization at Sudbury, ON, Canada. }\end{array}$ \\
\hline Chlorite & $\begin{array}{l}\text { Wilkinson et al. } \\
\text { (2015) [142] }\end{array}$ & $\begin{array}{l}\text { Chlorite compositions reflect proximity to ore in the propylitic } \\
\text { environment of porphyry deposits, potentially over as much as } \\
2.5 \mathrm{~km} \text {. The elements } \mathrm{K}, \mathrm{Li}, \mathrm{Mg}, \mathrm{Ca}, \mathrm{Sr}, \mathrm{Ba}, \mathrm{Ti}, \mathrm{V}, \mathrm{Mn}, \mathrm{Co}, \mathrm{Ni}, \mathrm{Zn} \text { and } \\
\mathrm{Pb} \text {, were shown to be likely incorporated in the lattice and display } \\
\text { spatial variation. Chlorite is proposed as a precise vectoring tool in } \\
\text { porphyry domains where few other vector tools are available. }\end{array}$ \\
\hline Apatite & $\begin{array}{l}\text { Mao et al. } \\
\text { (2016) [143] }\end{array}$ & $\begin{array}{l}\text { A compilation of apatite compositions shows that trace-element } \\
\text { compositions from various magmatic-hydrothermal deposits are } \\
\text { distinct from those in carbonatites and un-mineralized rocks. } \\
\text { Apatite composition shows potential for identifying specific types } \\
\text { of buried deposits. }\end{array}$ \\
\hline Magnetite & $\begin{array}{l}\text { Makvandi et al. } \\
(2016 a, b)[144,145]\end{array}$ & $\begin{array}{l}\text { The authors compare compositional data for magnetite from } \\
\text { VMS-type mineralization, associated bedrocks, and surrounding till } \\
\text { samples, showing the value of preserved magnetite for prospecting } \\
\text { in glaciated terranes. }\end{array}$ \\
\hline Pyrite & $\begin{array}{l}\text { Duran et al. }(2015 \text {, } \\
\text { 2016) }[106,113]\end{array}$ & $\begin{array}{l}\text { The two papers show that pyrite from magmatic } \mathrm{Ni}-\mathrm{Cu}-\mathrm{PGE} \text { and } \\
\text { hydrothermal deposits, and pentlandite from } \mathrm{Ni}-\mathrm{Cu} \text { sulphide and } \\
\text { PGE-dominated deposits, have distinct compositions, and can be } \\
\text { good indicators of mineralization type. }\end{array}$ \\
\hline
\end{tabular}

\section{Element Deportment, Geometallurgy and Forensic Applications}

Exploited mineral deposits ubiquitously contain elements other than those that are the major target of a mining operation. Some of these elements are advantageous, and if present in sufficient abundance, they can be recovered economically as by-products, either directly at the processing site, or as credits in concentrates and mattes sold on to the refiner. These include the so-called 'strategic' or 'critical' metals, such as $\mathrm{Ga}, \mathrm{Ge}, \mathrm{Co}, \mathrm{In}, \mathrm{Sn}, \mathrm{REE}, \mathrm{Nb}, \mathrm{Sc}$, and many others. Other elements may diminish the value of the ore and represent penalty elements. High contents of $\mathrm{As}, \mathrm{Sb}, \mathrm{Bi}$ and $\mathrm{Hg}$, for example, can make a copper ore difficult to process economically, or diminish the value or saleability of the concentrate [146]. LA-ICP-MS is an effective method to constrain which mineral or minerals contain the elements of interest (whether prospective by-product or penalty elements) in a specific deposit or ore province (e.g., indium in vein mineralization in SW England [147]), and the range and variation in absolute concentrations. Similarly, careful LA-ICP-MS analysis of individual minerals within mill feed or across the deposit can provide valuable information that feeds into a quantitative deportment model for penalty elements. Such approaches may require analysis of different minerals in a large number of samples, and/or examination of materials from different stages of the processing cycle. Together with microanalytical data acquired using other techniques, notably EPMA or SIMS, 
and automated QEMSCAN or MLA analysis on a large number of samples, the level of understanding of key mineralogical hosts for trace elements of interest or concern has advanced significantly in the past few years. This trend is likely to continue.

Such studies need to be designed to be as holistic as possible, and consider all minerals in a given assemblage as potential hosts to the penalty or by-product elements. The distribution of certain potentially valuable trace elements (for example, In, Ga, Ge, or Sn) may be complex with the elements of interest occurring, at various concentrations, in sulphides, oxides, rock-forming silicates, and even accessory phases (e.g., [148] in the case of indium). LA-ICP-MS data can make a significant contribution to calculation of a quantitative mineralogical balance following extensive mineralogical work to understand prevailing assemblages, and ideally the sequence of ore-forming processes. Although there currently exists a sound understanding of the preferred partitioning of key trace elements in base metal sulphide ores, allowing important hosts to be predicted (e.g., [59]), substantial knowledge gaps remain, particularly with respect to trace element partitioning in complex multi-phase assemblages [149].

LA-ICP-MS analysis can provide reliable information on mineral(s) hosting contaminant elements in mine tailings and in other solid media. This knowledge can be critical, e.g., for evaluating the behavior of those waste materials under exposure to groundwater.

A growing area of interest is to use the trace element signature specific to minerals formed in a given geological environment as a fingerprint to trace the origin of a sample. Published applications include successful attempts to fingerprint so-called 'conflict diamonds' [150,151], columbite-tantalite and other sought-after ores (e.g., [152,153]). Potential can also be recognised in areas such as uranium concentrates. Related fields of application include trace element microanalysis by LA-ICP-MS to determine the likely derivation of cultural heritage objects [154].

\section{Discussion}

\subsection{How Many Analyses?-And Which Elements?}

The authors are often asked how many data points are sufficient to characterize the trace element signature of a given mineral or phase. This will vary with the complexity of ore textures, and in particular, any intra-grain compositional zoning or the presence of multiple generations of the same mineral in a given sample or suite of samples. We cannot stress enough the importance of detailed petrological characterization, by optical and scanning electron microscopy, prior to any microanalytical work. This may entail the designation of textural sub-types and should assess any major compositional zoning in the material to be analyzed (i.e., visible optically or in back-scatter electron images). Such variation is likely to be mimicked by other elements present at lower concentrations.

Routine spot analysis by EPMA or LA-ICP-MS at the centers of 'clean-looking' grain is likely to introduce a systematic bias into the dataset, with elements that concentrate towards the rim or in specific domains within individual grains being potentially over- or under-estimated. Variation can be expected between samples from different parts of a given ore, and not uncommonly within a single polished section. Meaningful, quantitative evaluation of the distribution of, e.g., Au in pyrite, may therefore only be attained by determining abundances in a large number of representative samples. Other elements and other minerals, however, often show a more limited inter- and/or intra-sample variation and an accurate appraisal may be possible with a smaller dataset. Examples include the concentration of $\mathrm{Cd}, \mathrm{Mn}$ and $\mathrm{Hg}$ in sphalerite from metamorphosed ores, which often appear quite uniform on the deposit scale, at least in cases when only a single textural type (or generation) of sphalerite is recognized.

A further issue is the choice of isotopes to be measured. Reasonably rapid spot analysis requires sufficient dwell times for each element analyzed. The choice will be influenced by the type of mass spectrometer the number of isotopes measured; a quadrupole, for example, allows for analysis of more isotopes than a sector field instrument that may have longer magnet settling times. The maximum number of elements that can be analyzed at acceptable levels of precision using a quadrupole mass 
spectrometer is, in our experience, around 25-30, exceptionally as many as 35 . This may cause the user to have to choose from a larger number of elements, which might potentially be present. For common sulphides, a predictive understanding is beginning to emerge, whereby we can say with some reasonable certainty that sphalerite, for example, can contain $\mathrm{Mn}, \mathrm{Cd}, \mathrm{Hg}$ etc., even if we are unsure at what concentration levels, and that galena is likely to contain some Ag, $\mathrm{Bi}, \mathrm{Sb}, \mathrm{Tl}$ [49]. For other minerals, the choice may be more difficult-we have encountered Fe-oxides that contain more than 45 elements at measurable concentrations (authors unpublished data).

Similarly, LA-ICP-MS element maps of skarn garnet [53,95], for example, reveal recognizable patterns and measurable concentrations of more than half the periodic table (Figure 7), including several elements that were unexpected ( $\mathrm{Sb}, \mathrm{In}$, etc.). The choice of elements to be analyzed can be narrowed down somewhat by considering whether the elements are present in the standard(s) to be employed, and excluding those which are not, or by considering the likelihood that concentrations are, in any case below detection limit. Nevertheless, as pointed out by Zhu et al. [13], element maps expressed in counts-per-second values can provide valuable qualitative information on the relative distributions of elements not present in a given standard.

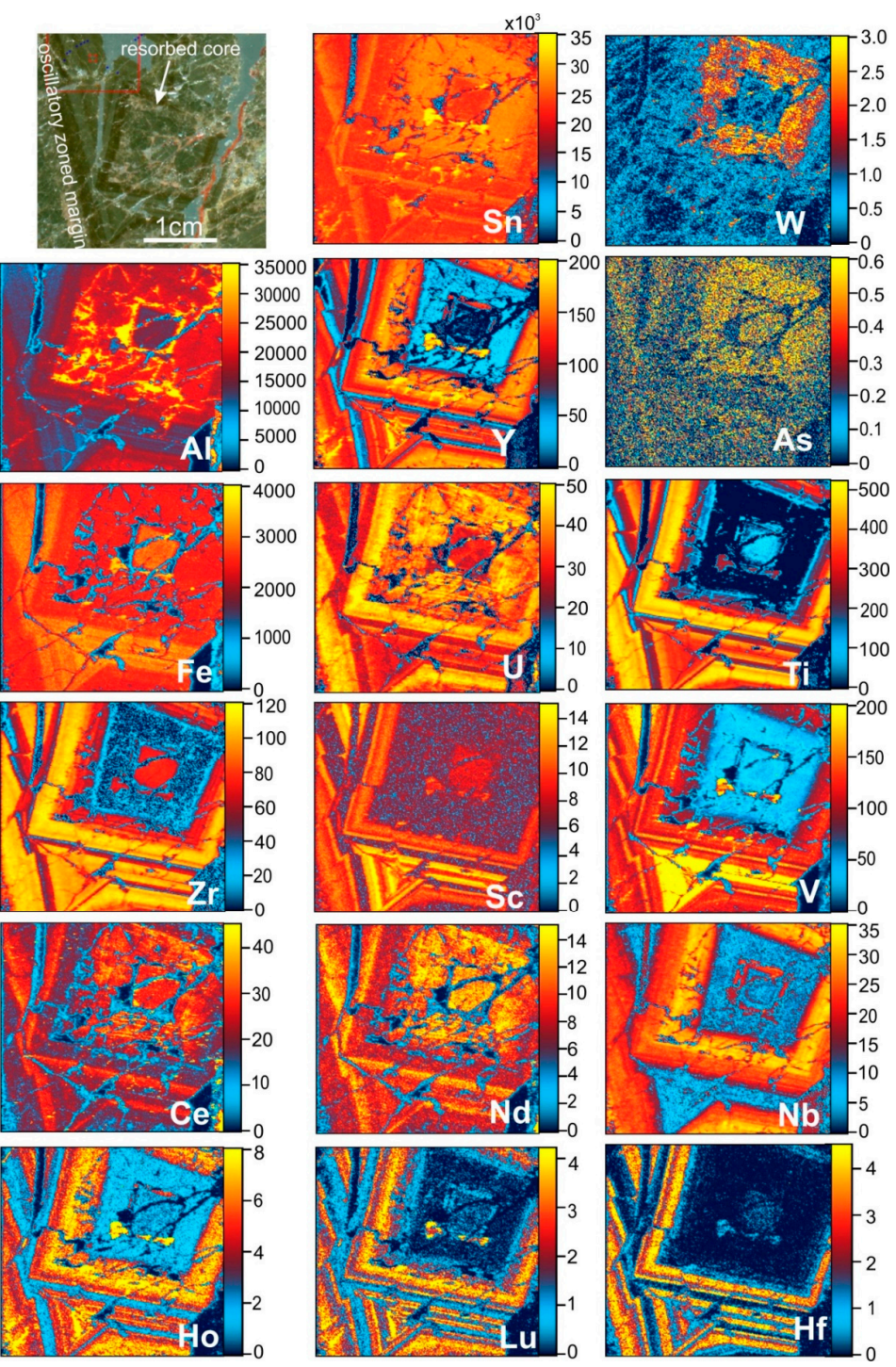

Figure 7. LA-ICP-MS element maps of zoned skarn garnet illustrating the abundance and diversity of trace elements present within the garnet structure. Scales in counts per second $\left(\times 10^{3}\right)$. Measured isotopes: ${ }^{118} \mathrm{Sn},{ }^{182} \mathrm{~W},{ }^{27} \mathrm{Al},{ }^{89} \mathrm{Y},{ }^{75} \mathrm{As},{ }^{56} \mathrm{Fe},{ }^{238} \mathrm{U},{ }^{47} \mathrm{Ti},{ }^{90} \mathrm{Zr},{ }^{45} \mathrm{Sc},{ }^{51} \mathrm{~V},{ }^{140} \mathrm{Ce},{ }^{146} \mathrm{Nd},{ }^{93} \mathrm{Nb},{ }^{165} \mathrm{Ho},{ }^{175} \mathrm{Lu},{ }^{178} \mathrm{Hf}$. 


\subsection{Statistical Treatment of LA-ICP-MS Data}

The relative ease and speed of data collection using automated LA-ICP-MS instrumentation facilitates the generation of large data volumes. This presents its own potential pitfalls, in that innovation in data processing has not kept pace with technical development. Interpretation of multi-element datasets is reliant on the choice of statistical methods used. These have been discussed by, among others, Winderbaum et al. (2012) [78], Marques de Sá (2014) [155], Frenzel et al. (2016) [156] and Makvandi et al. $(2016 a, b)[144,145]$. The choice of methodologies used depends on the nature of the dataset, the degree of variance at the sample or sub-population scale, and the objectives of the study. The latter may include the efficient discrimination of groupings that are rooted in temporally (genetically) distinct formation conditions, or spatial patterns that reflect systematic variation at the regional to mine scale.

For example, Winderbaum et al. (2012) [78] applied multivariate analysis to test the validity of pyrite grain classification methods based on morphological and textural factors. Parallel coordinate plots and correlation cluster analysis using Spearman's coefficients were found useful to identify unexpected elemental relationships, while principal component analysis and factor analysis demonstrate the presence of sub-classes of pyrite. Corroborated with geological data, statistical analysis provided evidence for successive generations of hydrothermal fluids, each introducing specific metals, and for partial or complete replacement of different minerals. Such weighted geochemical vectors are important for defining the evolution of geochemical signatures over time. By plotting specific components of such vectors (using, for example, Leapfrog 3D modeling software) spatial distribution can be assessed in terms of proximal to distal relative to a certain structure of interest or fluid source.

Statistical models do, however, need to account for the inherent variability and underlying relationships within such a dataset, necessitating mathematically-based, versatile, modulated approaches which could be more powerful and accurate than current approaches provided by off-the-shelf software. Such models need to acknowledge variables that do not show multivariate normal distributions and where there may be issues of scaling and tail dependency. The latter (the tendency for extreme outlying values to occur together) are crucial in the context of trace element signatures. The trace element signatures of individual minerals are governed by crystal structures and often-constrainable physical-chemical parameters making them far more sensitive to changes, and much less prone to averaging-out effects than is the case for whole-rock data. For example, if the relative concentrations and/or variation in element ratios can be correlated with the position of a mineral assemblage within a given ore system, exploration vectors can be developed for application in near-mine exploration, particularly for discrimination of proximal and distal positions relative to a hydrothermal fluid source.

\subsection{Current Trends and Future Opportunities}

The currently available data for many common ore and gangue minerals can assist with prediction of trace elements in the phases, and at what concentrations. As discussed above, minerals that are abundant in nature and widely distributed, and which display extensive trace element substitution, such as Fe-oxides or apatite, have particular appeal in that subtle variations in chemistry can be interpreted to reflect conditions of ore formation and represent a guide to ore in a variety of settings. Despite the considerable progress outlined above, more empirical data on a greater range of natural hydrothermal ore occurrences would be invaluable in understanding the fundamental controls on trace element distribution. This needs to be expanded to address the preferred partitioning behavior of elements valuable for petrogenetic interpretation (e.g., REE) or of potential economic value (e.g., certain 'critical' metals such as Sc, Ga or Ge).

Several recent publications have explored minerals for which little or no LA-ICP-MS trace element data have been available until now: carbonates [157,158], titanite [98,159], calcite and tourmaline [90], Ti-spinels and perovskite [160], or native gold [161]. Despite these efforts, the distribution of trace elements in certain matrices remains relatively poorly understudied. Data are particularly limited for 
common gangue carbonates (e.g., calcite and siderite), sulphates (e.g., anhydrite and barite), accessory minerals (e.g., titanite) and common products of hydrothermal alteration (e.g., chlorite, epidote, sericite, amphiboles and tourmaline). Considerable opportunity therefore exists for LA-ICP-MS studies addressing the partitioning behavior of potential by-product metals, such as Ga or Sn, in multi-phase sulphide-oxide-silicate assemblages. Even for relatively well-studied minerals, more trace element data, especially for rare elements, is welcome (e.g., in sphalerite [162]). Such additional data will assist in building holistic element distribution models, and will undoubtedly highlight the importance of minor and trace minerals as hosts for specific elements. The role played by minor minerals may be disproportionately large compared to their modal abundance. Care should, however, be taken to avoid interpretation of apparent hosts for trace elements caused by isotope interference. A related future objective would be the development of trace element geothermobarometers suitable for sulphide assemblages, based on more detailed understanding of element partitioning under equilibrium conditions.

Future technical developments are likely to lead to smaller spot sizes and better spatial resolutions, in turn facilitating insights into finely-zoned or intergrown minerals that cannot, at present, be unequivocally investigated by LA-ICP-MS. It can also be reasonably expected that future work will help ease persisting uncertainties about fractionation at the site of ablation or during transport to the mass spectrometer.

Although LA-ICP-MS is a destructive technique, complementary in situ trace element microanalysis by other techniques can be used to obtain for other information. We have demonstrated how small volumes can be extracted from the surface of a sample adjacent to laser ablation craters by focused ion beam-SEM methods, thinned and investigated by TEM, resulting in the identification of nanoparticles [50]. We have also performed synchrotron-based $\mu$-XANES investigations on sphalerite, shown by LA-ICP-MS spot analysis to contain hundreds of ppm Ge [70]. A further example is utilization of FIB-SEM-prepared foils from a sample of Bi-sulphosalts on which LA-ICP-MS spot analyses were conducted. These have been studied at the nanoscale to understand controls on trace and minor element incorporation [163].

A further topic worthy of research is the optimization of spot analysis and element mapping taking into consideration the orientation of mapped grains, given the possibility that trace elements may be preferentially incorporated along specific orientations, as has been demonstrated in fluorite [164]. This may be investigated by integrated use of LA-ICP-MS and EBSD studies. Although not using LA-ICP-MS, the multi-technique study of trace-element zoning in fluorapatite using BSE and CL imaging, and EPMA and $\mu$ PIXE/ $\mu$ PIGE mapping [165] is exemplary of the kind of approach destined to become more common in the future.

Despite the publication of large volumes of LA-ICP-MS trace element data in recent years, and expansion of the method to new matrices and applications, there have been remarkably few studies, which have evaluated the performance of reference materials in different laboratories, or comparative studies on different mineral matrices. More standard development needs to be carried out in order to improve laboratory LA-ICP-MS practice, offer innovative strategies for preparation of reference materials [166,167], and so contribute to better LA-ICP-MS analyses. This is particularly true for standards needed to analyze the range of sulphides, oxides, phosphates and other common minerals in hydrothermal ore deposits. Ways in which this might be done include better matrix matching, homogeneity, reproducibility, and not least, accessibility to optimal reference materials. Several recent developments in standard development [168,169] show how solutions are being sought to overcome some of the limitations highlighted in this contribution.

\section{Conclusions}

LA-ICP-MS is a rapid, relatively inexpensive method to obtain large volumes of useful trace element data without undue time-consuming sample preparation. Comprehensive optical and SEM characterization of ore textures is, however, essential prior to analysis. Care should also be taken to 
select analytical spots and to consider that if the distribution of trace elements is heterogeneous at the grain scale. Data processing and interpretation also needs to follow protocols that acknowledge the presence of outliers related to mineral inclusions. Results can underpin models of ore genesis, be applied in mineral exploration, and, indirectly, guide optimal exploitation of existing ore deposits. Rapidly expanding datasets for a variety of mineral matrices provide the foundation necessary to evaluate variations in samples from different geological settings and the issue of 'noise' within individual samples that can hamper interpretation.

Acknowledgments: We thank our colleagues and $\mathrm{Ph} . \mathrm{D}$. students for helpful discussion during preparation of this paper. Figures 1 and 7 derive from original data presented in unpublished Bachelor's and Ph.D. theses, by Matthew Fargher and Roniza Ismail, respectively. Ideas in this contribution were first raised in an invited plenary presentation at the 14th Quadrennial IAGOD meeting (Kunming, 2014). The conference organizers are thanked for their support. Nigel Cook acknowledge support from the Australian Research Council Hub for Australian Copper Uranium (project number: IH130200033), BHP Billiton Olympic Dam, OZ Minerals, and the South Australian Department of State Development (DSD). Nigel Cook acknowledges support from the 'FOX' project (Trace elements in iron oxides: deportment, distribution and application in ore genesis, geochronology, exploration and mineral processing), supported by BHP Billiton Olympic Dam and the Government of South Australia Mining and Petroleum Services Centre of Excellence. Last but not least, we gratefully acknowledge comments from three journal reviewers, which much assisted with revision of this review.

Author Contributions: Nigel Cook conceived this contribution; Cristiana L. Ciobanu contributed previously unpublished data from internal reports. Nigel Cook and Cristiana L. Ciobanu wrote the paper with contributions from Luke George, Benjamin Wade, Zhi-Yong Zhu and Kathy Ehrig.

Conflicts of Interest: The authors declare no conflict of interest.

\section{References}

1. Sylvester, P. Laser Ablation ICP-MS in the Earth Sciences: Current Practices and Outstanding Issues; Mineralogical Association of Canada: Québec, QC, Canada, 2008; Volume 40.

2. Paton, C.; Hellstrom, J.; Paul, B.; Woodhead, J.; Hergt, J. Iolite: Freeware for the visualisation and processing of mass spectrometric data. J. Anal. Atom. Spectrom. 2011, 26, 2508-2518. [CrossRef]

3. Gilbert, S.E.; Danyushevsky, L.V.; Rodemann, T.; Shimizu, N.; Gurenko, A.; Meffre, S.; Thomas, H.; Large, R.R.; Death, D. Optimisation of laser parameters for the analysis of sulphur isotopes in sulphide minerals by laser ablation ICP-MS. J. Anal. Atom. Spectrom. 2014, 29, 1042-1051. [CrossRef]

4. Woodhead, J.; Hergt, J.; Meffre, S.; Large, R.R.; Danyushevsky, L.; Gilbert, S. In situ Pb-isotope analysis of pyrite by laser ablation (multi-collector and quadrupole) ICPMS. Chem. Geol. 2009, 262, 344-354. [CrossRef]

5. Darling, J.R.; Storey, C.D.; Hawkesworth, C.J.; Lightfoot, P.C. In-situ Pb isotope analysis of Fe-Ni-Cu sulphides by laser ablation multi-collector ICPMS: New insights into ore formation in the Sudbury impact melt sheet. Geochim. Cosmochim. Acta 2012, 99, 1-17. [CrossRef]

6. McFarlane, C.R.M.; Luo, Y. U-Pb Geochronology using $193 \mathrm{~nm}$ excimer LA-ICP-MS optimized for in situ accessory mineral dating in thin sections. Geosci. Can. 2012, 39, 158-172.

7. Ciobanu, C.L.; Wade, B.; Cook, N.J.; Schmidt Mumm, A.; Giles, D. Uranium-bearing hematite from the Olympic Dam Cu-U-Au deposit, South Australia: A geochemical tracer and reconnaissance $\mathrm{Pb}-\mathrm{Pb}$ geochronometer. Precambr. Res. 2013, 238, 129-147. [CrossRef]

8. Courtney-Davies, L.; Zhu, Z.Y.; Ciobanu, C.L.; Wade, B.S.; Cook, N.J.; Ehrig, K.; Cabral, A.R.; Kennedy, A. Matrix-matched iron-oxide laser ablation ICP-MS U-Pb geochronology using mixed solution standards. Minerals 2016, 6, 85. [CrossRef]

9. Thompson, J.; Meffre, S.; Maas, R.; Kamenetsky, V.; Kamenetsky, M.; Goemann, K.; Ehrig, K.; Danyushevsky, L. Matrix effects in $\mathrm{Pb} / \mathrm{U}$ measurements during LA-ICP-MS analysis of the mineral apatite. J. Anal. Atom. Spectrom. 2016, 31, 1206-1215. [CrossRef]

10. Li, C.Y.; Zhang, R.Q.; Ding, X.; Ling, M.X.; Fan, W.M.; Sun, W.D. Dating cassiterite using laser ablation ICP-MS. Ore Geol. Rev. 2016, 72, 313-322. [CrossRef]

11. McFarlane, C.R.M. Allanite U-Pb geochronology by $193 \mathrm{~nm}$ LA ICP-MS using NIST610 glass for external calibration. Chem. Geol. 2016, 438, 91-102. [CrossRef]

12. McFarlane, C.; Lentz, D.; Dehnavi, A.S. Pb-isotopic study of galena by LA-Q-ICP-MS: Testing a new methodology with applications to base-metal sulphide deposits. Minerals 2016, 6, 96. [CrossRef] 
13. Zhu, Z.Y.; Yang, T.; Ciobanu, C.L.; Cook, N.J.; Zhao, K.D.; Jiang, S.Y. Mapping of S isotopes and trace elements in sulfides by LA-(MC)-ICP-MS: Potential problems and implications. Minerals 2016, 6, 110.

14. Heinrich, C.A.; Pettke, T.; Halter, W.E.; Aigner-Torres, M.; Audétat, A.; Günther, D.; Hattendorf, B.; Bleiner, D.; Guillong, M.; Horn, I. Quantitative multi-element analysis of minerals, fluid and melt inclusions by laser-ablation inductively-coupled-plasma mass-spectrometry. Geochim. Cosmochim. Acta 2003, 67, 3473-3497. [CrossRef]

15. Zajacz, Z.; Halter, W. LA-ICPMS analyses of silicate melt inclusions in co-precipitated minerals: Quantification, data analysis and mineral/melt partitioning. Geochim. Cosmochim. Acta 2007, 71, 1021-1040. [CrossRef]

16. Watson, E.B.; Harrison, T.M. Zircon thermometer reveals minimum melting conditions on earliest Earth. Science 2005, 308, 841-844. [CrossRef] [PubMed]

17. Hayden, L.A.; Watson, E.B.; Wark, D.A. A thermobarometer for sphene (titanite). Contrib. Mineral. Petrol. 2008, 155, 529-540. [CrossRef]

18. Russo, R.E.; Mao, X.L.; Gonzalez, J.J.; Mao, S.S. Femtosecond laser ablation ICP-MS. J. Anal. Atom. Spectrom. 2002, 17, 1072-1075. [CrossRef]

19. Koch, J.; Günther, D. Femtosecond laser ablation inductively coupled plasma mass spectrometry: Achievements and remaining problems. Anal. Bioanal. Chem. 2007, 387, 149-153. [CrossRef] [PubMed]

20. Garcia, C.C.; Lindner, H.; von Bohlen, A.; Vadla, C.; Niemax, K. Elemental fractionation and stoichiometric sampling in femtosecond laser ablation. J. Anal. Atom. Spectrom. 2008, 23, 470-478. [CrossRef]

21. Ohata, M.; Tabersky, D.; Glaus, R.; Koch, J.; Hattendorf, B.; Günther, D.J. Comparison of 795 nm and 265 nm femtosecond and $193 \mathrm{~nm}$ nanosecond laser ablation inductively coupled plasma mass spectrometry for the quantitative multi-element analysis of glass materials. J. Anal. Atom. Spectrom. 2014, 29, 1345-1353. [CrossRef]

22. Wohlgemuth-Ueberwasser, C.C.; Jochum, K.P. Capability of fs-LA-ICP-MS for sulfide analysis in comparison to ns-LA-ICP-MS: Reduction of laser induced matrix effects? J. Anal. Atom. Spectrom. 2015, 30, 2469-2480. [CrossRef]

23. Zhu, Z.Y.; Jiang, S.Y.; Yang, T.; Ciobanu, C.L.; Cook, N.J. Sulfur isotope fractionation in pyrite during laser ablation: Implications for laser ablation multiple collector inductively coupled plasma mass spectrometry mapping. Chem. Geol. 2016, in press.

24. Gilbert, S.E.; Danyushevsky, L.V.; Goemann, K.; Death, D. Fractionation of sulphur relative to iron during laser ablation-ICP-MS analyses of sulphide minerals: Implications for quantification. J. Anal. Atom. Spectrom. 2014, 29, 1024-1033. [CrossRef]

25. Günther, D.; von Quadt, A.; Wirz, A.; Cousin, H.; Dietrich, V.J. Elemental analyses using laser ablation-inductively coupled plasma-mass spectrometry (LA-ICP-MS) of geological samples fused with $\mathrm{Li}_{2} \mathrm{~B}_{4} \mathrm{O}_{7}$ and calibrated without matrix-matched standards. Mikrochim. Acta 2001, 136, 101-107. [CrossRef]

26. Jackson, S.E.; Günther, D. The nature and sources of laser induced isotopic fractionation in laser ablation-multicollector-inductively coupled plasma-mass spectrometry. J. Anal. Atom. Spectrom. 2003, 18, 205-212. [CrossRef]

27. Günther, D.; Koch, J. Formation of aerosols generated by laser ablation and their impact on elemental fractionation in LA-ICP-MS. In Laser Ablation ICP-MS in the Earth Sciences: Current Practices and Outstanding Issues; Sylvester, P., Ed.; Mineralogical Association of Canada: Québec, QC, Canada, 2008; Volume 40, pp. 19-34.

28. Sylvester, P.J. Matrix effects in laser ablation ICP-MS. In Laser Ablation ICP-MS in the Earth Sciences: Current Practices and Outstanding Issues; Mineralogical Association of Canada: Québec, QC, Canada, 2008; Volume 40, pp. 67-78.

29. Norman, M.D.; Pearson, N.J.; Sharma, A.; Griffin, W.L. Quantitative analysis of trace elements in geological materials by laser ablation ICPMS: Instrumental operating conditions and calibration values of NIST glasses. Geostand. Newslett. 1996, 20, 247-261. [CrossRef]

30. Norman, M.; Robinson, P.; Clark, D. Major- and trace-element analysis of sulfide ores by laser-ablation ICP-MS, solution ICP-MS, and XRF: New data on international reference materials. Can. Mine. 2003, 41, 293-305. [CrossRef] 
31. Wohlgemuth-Ueberwasser, C.C.; Ballhaus, C.; Berndt, J.; Stotter, V.; Meisel, T. Synthesis of PGE sulphide standards for laser ablation inductively coupled plasma mass spectrometry (LA-ICP-MS). Contrib. Mineral. Petrol. 2007, 154, 607-617. [CrossRef]

32. Danyushevsky, L.; Robinson, P.; Gilbert, S.; Norman, M.; Large, R.; McGoldrick, P.; Shelley, M. Routine quantitative multi-element analysis of sulphide minerals by laser ablation ICP-MS: Standard development and consideration of matrix effects. Geochem. Explor. Environ. Anal. 2011, 11, 51-60. [CrossRef]

33. Lin, J.; Liu, Y.S.; Yang, Y.H.; Hu, Z.C. Calibration and correction of LA-ICP-MS and LA-MC-ICP-MS analyses for element contents and isotopic ratios. Solid Earth Sci. 2016, 1, 5-27. [CrossRef]

34. Gilbert, S.; Danyushevsky, L.; Robinson, P.; Wohlgemuth-Ueberwasser, C.; Pearson, N.; Savard, D.; Norman, M.; Hanley, J. A comparative study of five reference materials and the Lombard meteorite for the determination of the platinum-group elements and gold by LA-ICP-MS. Geostand. Geoanal. Res. 2013, 37, 51-64. [CrossRef]

35. Savard, D.; Barnes, S.J.; Sunder Raju, P.V. Accurate LA-ICP-MS calibration for magnetite analysis using multiple reference materials. Geochim. Cosmochim. Acta 2010, 74, A914.

36. Tabersky, D.; Luechinger, N.A.; Rossier, M.; Reusser, E.; Hametner, K.; Aeschlimann, B.; Frick, D.A.; Halim, S.C.; Thompson, J.; Danyushevsky, L.; Günther, D. Development and characterization of custom-engineered and compacted nanoparticles as calibration materials for quantification using LA-ICP-MS. J. Anal. Atom. Spectrom. 2014, 29, 955-962. [CrossRef]

37. Jochum, K.P.; Weis, U.; Stoll, B.; Kuzmin, D.; Yang, Q.; Raczek, I.; Jacob, D.E.; Stracke, A.; Birbaum, K.; Frick, D.A. Determination of reference values for NIST SRM 610-617 glasses following ISO guidelines. Geostand. Geoanal. Res. 2011, 35, 397-429. [CrossRef]

38. Nadoll, P.; Koenig, A.E. LA-ICP-MS of magnetite: Methods and reference materials. J. Anal. Atom. Spectrom. 2011, 26, 1872-1877. [CrossRef]

39. Wilson, S.A. The Collection, Preparation, and Testing of USGS Reference Material BCR-2, Columbia River, Basalt; Open-File Report; U.S. Geological Survey: Reston, VA, USA, 1997.

40. Jochum, H.P.; Willbold, M.; Raczek, I.; Stoll, B.; Herwig, K. Chemical characterisation of the USGS Reference Glasses GSA-1G, GSC-1G, GSD-1G, GSE-1G, BCR-2G, BHVO-2G and BIR-1G using EPMA, ID-TIMS, ID-ICP-MS and LA-ICP-MS. Geostand. Geoanal. Res. 2005, 29, 285-302. [CrossRef]

41. Flanagan, F.J. Descriptions and Analysis of Eight New USGS Rock Standards; U.S. Geological Survey Professional Paper; U.S. Government Printing Office: Washington, DC, USA, 1976; Volume 840.

42. Wilson, S.A.; Ridley, W.I.; Koenig, A.E. Development of sulphide calibration standards for the laser ablation inductively-coupled plasma mass spectrometry technique. J. Anal. Atom. Spectrom. 2002, 17, 406-409. [CrossRef]

43. Yuan, J.H.; Zhan, X.C.; Fan, C.Z.; Zhao, L.H.; Sun, D.Y.; Jia, Z.R.; Hu, M.Y.; Kuai, L.J. Quantitative analysis of sulfide minerals by laser ablation-inductively coupled plasma-mass spectrometry using glass reference materials with matrix normalization plus sulfur internal standardization calibration. Chin. J. Anal. Chem. 2012, 40, 201-207. [CrossRef]

44. Ding, L.; Yang, G.; Xia, F.; Lenehan, C.E.; Qian, G.; McFadden, A.; Brugger, J.; Zhang, X.; Chen, G.; Pring, A. A LA-ICP-MS sulphide calibration standard based on a chalcogenide glass. Mineral. Mag. 2011, 75, 279-287. [CrossRef]

45. Jackson, S.E.; Fryer, B.J.; Gosse, W.; Healey, D.C.; Longerich, H.P.; Strong, D.F. Determination of the precious metals in geological materials by ICP-MS with nickel sulfide fire assay collection and tellurium coprecipitation. Chem. Geol. 1990, 83, 119-132. [CrossRef]

46. Sung, Y.H.; Brugger, J.; Ciobanu, C.L.; Pring, A.; Skinner, W.; Nugus, M. Invisible gold in arsenian pyrite and arsenopyrite from a multistage Archaean gold deposit: Sunrise Dam, Eastern Goldfields Province, Western Australia. Mineral. Depos. 2009, 44, 765-791. [CrossRef]

47. Cook, N.J.; Ciobanu, C.L.; Mao, J.W. Textural control on gold distribution in As-free pyrite from the Dongping, Huangtuliang and Hougou gold deposits, North China Craton, (Hebei Province, China). Chem. Geol. 2009, 264, 101-121. [CrossRef]

48. Cook, N.J.; Ciobanu, C.L.; Meria, D.; Silcock, D.; Wade, B. Arsenopyrite-pyrite association in an orogenic gold ore: Tracing mineralization history from textures and trace elements. Econ. Geol. 2013, 108, 1273-1283. [CrossRef] 
49. Ciobanu, C.L.; Cook, N.J.; Utsunomiya, S.; Pring, A.; Green, L. Focussed ion beam-transmission electron microscopy applications in ore mineralogy: Bridging micron- and nanoscale observations. Ore Geol. Rev. 2011, 42, 6-31. [CrossRef]

50. Ciobanu, C.L.; Cook, N.J.; Utsunomiya, S.; Kogagwa, M.; Green, L.; Gilbert, S.; Wade, B. Gold-telluride nanoparticles revealed in arsenic-free pyrite. Am. Mineral. 2012, 97, 1515-1518. [CrossRef]

51. Junge, M.; Wirth, R.; Oberthür, T.; Melcher, F. Mineralogical siting of platinum-group elements in pentlandite from the Bushveld Complex, South Africa. Mineral. Depos. 2015, 50, 41-54. [CrossRef]

52. Zhang, J.; Deng, J.; Chen, H.Y.; Yang, L.Q.; Cooke, D.; Danyushevsky, L.; Gong, Q.J. LA-ICP-MS trace element analysis of pyrite from the Chang'an gold deposit, Sanjiang region, China: Implication for ore-forming process. Gondwana Res. 2014, 26, 557-575. [CrossRef]

53. Ismail, R.; Ciobanu, C.L.; Cook, N.J.; Teale, G.S.; Giles, D.; Schmidt Mumm, A.; Wade, B. Rare earths and other trace elements in minerals from skarn assemblages, Hillside iron oxide-copper-gold deposit, Yorke Peninsula, South Australia. Lithos 2014, 184-187, 456-477. [CrossRef]

54. Ubide, T.; McKenna, C.A.; Chew, D.M.; Kamber, B.S. High-resolution LA-ICP-MS trace element mapping of igneous minerals: In search of magma histories. Chem. Geol. 2015, 409, 157-168. [CrossRef]

55. Ulrich, T.; Kamber, B.S.; Jugo, P.J.; Tinkham, D.K. Imaging element-distribution patterns in minerals by laser ablation-Inductively coupled plasma-Mass spectrometry (LA-ICP-MS). Can. Mineral. 2009, 47, 1001-1012. [CrossRef]

56. Agangi, A.; Hofmann, A.; Wohlgemuth-Ueberwasser, C.C. Pyrite zoning as a record of mineralization in the Ventersdorp contact Reef, Witwatersrand Basin, South Africa. Econ. Geol. 2013, 108, 1243-1272. [CrossRef]

57. Gagnevin, D.; Menuge, J.F.; Kronz, A.; Barrie, C.; Boyce, A.J. Minor Elements in Layered Sphalerite as a Record of Fluid Origin, Mixing, and Crystallization in the Navan Zn-Pb Ore Deposit, Ireland. Econ. Geol. 2014, 109, 1513-1528. [CrossRef]

58. Maslennikov, V.V.; Maslennikova, S.P.; Large, R.R.; Danyushevsky, L.V. Study of trace element zonation in vent chimneys from the Silurian Yaman-Kasy volcanic-hosted massive sulfide deposit (Southern Urals, Russia) using laser ablation-inductively coupled plasma mass spectrometry (LA-ICPMS). Econ. Geol. 2009, 104, 1111-1141. [CrossRef]

59. George, L.L.; Cook, N.J.; Ciobanu, C.L. Partitioning of trace elements in co-crystallized sphalerite-galena-chalcopyrite hydrothermal ores. Ore Geol. Rev. 2016, 77, 97-116. [CrossRef]

60. Li, K.; Etschmann, B.; Rae, N.; Reith, F.; Ryan, C.G.; Kirkham, R.; Howard, D.; Rosa, D.R.N.; Zammit, C.; Pring, A.; et al. Ore petrography using megapixel X-ray imaging: Rapid insights into element distribution and mobilization in complex Pt and U-Ge-Cu Ores. Econ. Geol. 2016, 111, 487-502. [CrossRef]

61. Cook, N.J.; Ciobanu, C.L.; Pring, A.; Skinner, W.; Danyushevsky, L.; Shimizu, M.; Saini-Eidukat, B.; Melcher, F. Trace and minor elements in sphalerite: A LA-ICP-MS study. Geochim. Cosmochim. Acta 2009, 73, 4761-4791. [CrossRef]

62. Nadoll, P.; Angerer, T.; Mauk, J.L.; French, D.; Walshe, J. The chemistry of hydrothermal magnetite: A review. Ore Geol. Rev. 2014, 61, 1-32. [CrossRef]

63. Ciobanu, C.L.; Cook, N.J.; Pring, A.; Brugger, J.; Danushevsky, L.; Shimizu, M. 'Invisible gold' in bismuth chalcogenides. Geochim. Cosmochim. Acta 2009, 73, 1970-1999. [CrossRef]

64. Ciobanu, C.L.; Cook, N.J.; Kelson, C.R.; Guerin, R.; Kalleske, N.; Danyushevsky, L. Trace element heterogeneity in molybdenite fingerprints stages of mineralization. Chem. Geol. 2013, 347, 175-189. [CrossRef]

65. Ye, L.; Cook, N.J.; Ciobanu, C.L.; Liu, Y.P.; Zhang, Q.; Gao, W.; Yang, Y.L.; Danyushevsky, L.V. Trace and minor elements in sphalerite from base metal deposits in South China: A LA-ICPMS study. Ore Geol. Rev. 2011, 39, 188-217. [CrossRef]

66. Cook, N.J.; Ciobanu, C.L.; Brugger, J.; Etschmann, B.; Howard, D.J.; de Jonge, M.; Ryan, C.G.; Paterson, D. Determination of the oxidation state of $\mathrm{Cu}$ in substituted $\mathrm{Cu}-\mathrm{In}$-Fe-bearing sphalerite via $\mu$-XANES spectroscopy. Am. Mineral. 2012, 97, 476-479. [CrossRef]

67. Murakami, H.; Ishihara, S. Trace elements of indium-bearing sphalerite from tin-polymetallic deposits in Bolivia, China and Japan: A femto-second LA-ICPMS study. Ore Geol. Rev. 2013, 53, 223-243. [CrossRef]

68. Lockington, J.; Cook, N.J.; Ciobanu, C.L. Trace and minor elements in sphalerite from metamorphosed sulphide deposits. Mineral. Petrol. 2014, 108, 873-890. [CrossRef] 
69. Belissont, R.; Boiron, M.-C.; Luais, B.; Cathelineau, M. LA-ICP-MS analyses of minor and trace elements and bulk Ge isotopes in zoned Ge-rich sphalerites from the Noailhac-Saint-Salvy deposit (France): Insights into incorporation mechanisms and ore deposition processes. Geochim. Cosmochim. Acta 2014, 126, 518-540. [CrossRef]

70. Cook, N.J.; Etschmann, B.; Ciobanu, C.L.; Geraki, K.; Howard, D.L.; Williams, T.; Rae, N.; Pring, A.; Chen, G.; Johannessen, B.; et al. Distribution and substitution mechanism of Ge in a Ge-(Fe)-bearing sphalerite. Minerals 2015, 5, 117-132. [CrossRef]

71. Butler, I.B.; Nesbitt, R.W. Trace element distributions in the chalcopyrite wall of a black smoker chimney: Insights from laser ablation inductively coupled plasma mass spectrometry (LA-ICP-MS). Earth Plan. Sci. Lett. 1999, 167, 335-345. [CrossRef]

72. Wohlgemuth-Ueberwasser, C.C.; Viljoen, F.; Petersen, S.; Vorster, C. Distribution and solubility limits of trace elements in hydrothermal black smoker sulfides: An in-situ LA-ICP-MS study. Geochim. Cosmochim. Acta 2015, 159, 16-41. [CrossRef]

73. George, L.L.; Cook, N.J.; Ciobanu, C.L. Trace Elements in Chalcopyrite. Mineral. Mag. In press.

74. Cook, N.J.; Ciobanu, C.L.; Danyushevsky, L.V.; Gilbert, S. Minor elements in bornite and associated Cu-(Fe)-sulfides: A LA-ICPMS study. Geochim. Cosmochim. Acta 2011, 73, 4761-4791. [CrossRef]

75. George, L.; Cook, N.J.; Ciobanu, C.L.; Wade, B. Trace and minor elements in galena: A reconnaissance LA-ICP-MS study. Am. Mineral. 2015, 100, 548-569. [CrossRef]

76. Large, R.R.; Maslenikov, V.V.; Robert, F.; Danyushevsky, L.V.; Chang, Z. Multistage sedimentary and metamorphic origin of pyrite and gold in the giant Sukhoi log deposit, Lena Gold Province, Russia. Econ. Geol. 2007, 102, 1233-1267. [CrossRef]

77. Large, R.R.; Danyushevsky, L.; Hollit, C.; Maslennikov, V.; Meffre, S.; Gilbert, S.; Bull, S.; Scott, R.; Emsbo, P.; Thomas, H.; et al. Gold and trace element zonation in pyrite using a laser imaging technique: Implications for the timing of gold in orogenic and Carlin-style sediment-hosted deposits. Econ. Geol. 2009, 104, 635-668. [CrossRef]

78. Winderbaum, L.; Ciobanu, C.L.; Cook, N.J.; Paul, M.; Metcalfe, A.; Gilbert, S. Multivariate analysis of an LA-ICP-MS trace element dataset for pyrite. Mathematical Geosci. 2012, 44, 823-842. [CrossRef]

79. Ingham, E.S.; Cook, N.J.; Cliff, J.; Ciobanu, C.L.; Huddleston, A. A combined chemical, isotopic and microstructural study of pyrite from roll-front uranium deposits, Lake Eyre Basin, South Australia. Geochim. Cosmochim. Acta 2014, 125, 440-465. [CrossRef]

80. Large, R.R.; Halpin, J.A.; Danyushevsky, L.V.; Maslennikov, V.V.; Bull, S.W.; Long, J.A.; Gregory, D.D.; Lounejeva, E.; Lyons, T.W.; Sack, P.J.; et al. Trace element content of sedimentary pyrite as a new proxy for deep-time ocean-atmosphere evolution. Earth Plan. Sci. Lett. 2014, 389, 209-220. [CrossRef]

81. Morey, A.A.; Tomkins, A.G.; Bierlein, F.P.; Weinberg, R.F.; Davidson, G.J. Bimodal distribution of gold in pyrite and Arsenopyrite: Examples from the Archean Boorara and Bardoc Shear Systems, Yilgarn Craton, Western Australia. Econ. Geol. 2008, 103, 599-614. [CrossRef]

82. Lawley, C.J.M.; Creaser, R.A.; Jackson, S.E.; Yang, Z.P.; Davis, B.J.; Pehrsson, S.J.; Dubé, B.; Mercier-Langevin, P.; Vaillancourt, D. Unraveling the western Churchill province Paleoproterozoic Gold Metallotect: Constraints from Re-Os Arsenopyrite and U-Pb Xenotime geochronology and LA-ICP-MS Arsenopyrite trace element chemistry at the BIF-Hosted meliadine gold district, Nunavut, Canada. Econ. Geol. 2015, 110, 1425-1454. [CrossRef]

83. Deyell, C.L.; Hedenquist, J.W. Trace element geochemistry of enargite in the Mankayan District, Philippines. Econ. Geol. 2011, 106, 1465-1478. [CrossRef]

84. Barnes, S.J.; Prichard, H.M.; Cox, R.A.; Fisher, P.C.; Godel, B. The location of the chalcophile and siderophile elements in platinum-group element ore deposits (a textural, microbeam and whole rock geochemical study): Implications for the formation of the deposits. Chem. Geol. 2008, 248, 295-317. [CrossRef]

85. Dare, S.A.S.; Barnes, S.J.; Beaudoin, G.; Méric, J.; Boutroy, E.; Potvin-Doucet, C. Trace elements in magnetite as petrogenetic indicators. Mineral. Depos. 2014, 49, 785-796. [CrossRef]

86. Pagé, P.; Barnes, S.J. Using trace elements in chromites to constrain the origin of podiform chromitites in the Thetford Mines Ophiolite, Quebec, Canada. Econ. Geol. 2009, 104, 997-1018. [CrossRef]

87. O’Brien, J.J.; Spry, P.G.; Teale, G.S.; Jackson, S.E.; Rogers, D. Major and trace element chemistry of gahnite as an exploration guide to Broken Hill-Type Pb-Zn-Ag Mineralization in the Broken Hill Domain, New South Wales, Australia. Econ. Geol. 2015, 110, 1027-1057. [CrossRef] 
88. Goldmann, S.; Melcher, F.; Gäbler, H.-E.; Dewaele, S.; De Clerq, F.; Muchez, P. Mineralogy and trace element chemistry of ferberite/reinite from Tungsten Deposits in Central Rwanda. Minerals 2013, 3, 121-144. [CrossRef]

89. Song, G.X.; Qin, K.Z.; Li, G.M.; Evans, N.J.; Chen, L. Scheelite elemental and isotopic signatures: Implications for the genesis of skarn-type W-Mo deposits in the Chizhou Area, Anhui Province, Eastern China. Am. Mineral. 2014, 99, 303-317. [CrossRef]

90. Hazarika, P.; Mishra, B.; Pruseth, K.L. Scheelite, apatite, calcite and tourmaline compositions from the late Archean Hutti orogenic gold deposit: Implications for analogous two stage ore fluids. Ore Geol. Rev. 2016, 72, 989-1003. [CrossRef]

91. Raju, P.V.S.; Hart, C.J.R.; Sangurmath, P. Scheelite geochemical signatures by LA-ICP-MS and potential for rare earth elements from Hutti Gold Mines and fingerprinting ore deposits. J. Afr. Earth Sci. 2016, 114, 220-227. [CrossRef]

92. Cook, N.J.; Ciobanu, C.L.; O’Rielly, D.; Wilson, K.; Das, K.; Wade, B. Mineral chemistry and element partitioning in hydrothermal Rare Earth Element (REE) mineralization, Browns Ranges, Western Australia. Lithos 2013, 172-173, 192-213. [CrossRef]

93. Smith, M.P.; Henderson, P.; Jeffries, T.E.R.; Long, J.; Williams, C.T. The rare earth elements and uranium in garnets from the Beinn an Dubhaich Aureole, Skye, Scotland, UK: Constraints on processes in a dynamic hydrothermal system. J. Petrol. 2004, 45, 457-484. [CrossRef]

94. Gaspar, M.; Knaack, C.; Meinert, L.D.; Moretti, R. REE in skarn systems: A LA-ICP-MS study of garnets from the Crown Jewel gold deposit. Geochim. Cosmochim. Acta 2008, 72, 185-205. [CrossRef]

95. Xu, J.; Ciobanu, C.L.; Cook, N.J.; Zheng, Y.; Sun, X.; Wade, B.P. Skarn formation and trace elements in garnet and associated minerals from Zhibula copper deposit, Gangdese Belt, southern Tibet. Lithos 2016, 262, 213-231. [CrossRef]

96. Kontonikas-Charos, A.; Ciobanu, C.L.; Cook, N.J. Albitization and redistribution of REE and Y in IOCG systems: Insights from Moonta-Wallaroo, Yorke Peninsula, South Australia. Lithos 2014, 208-209, 178-201. [CrossRef]

97. Smith, M.P.; Storey, C.D.; Jeffries, T.E.; Ryan, C. In situ U-Pb and trace element analysis of accessory minerals in the Kiruna District, Norrbotten, Sweden: New constraints on the timing and origin of mineralization. J. Petrol. 2009, 50, 2063-2094. [CrossRef]

98. Fu, Y.; Sun, X.M.; Zhou, H.Y.; Lin, H.; Yang, T.J. In-situ LA-ICP-MS U-Pb geochronology and trace elements analysis of polygenetic titanite from the giant Beiya gold-polymetallic deposit in Yunnan Province, Southwest China. Ore Geol. Rev. 2016, 77, 43-56. [CrossRef]

99. He, H.L.; Yu, S.Y.; Song, X.Y.; Du, Z.S.; Dai, Z.H.; Zhou, T.; Xie, W. Origin of nelsonite and Fe-Ti oxides ore of the Damiao anorthosite complex, NE China: Evidence from trace element geochemistry of apatite, plagioclase, magnetite and ilmenite. Ore Geol. Rev. 2016, 79, 367-381. [CrossRef]

100. She, Y.W.; Song, X.Y.; Yu, S.Y.; Chen, L.M.; Zheng, W.Q. Apatite geochemistry of the Taihe layered intrusion, SW China: Implications for the magmatic differentiation and the origin of apatite-rich Fe-Ti oxide ores. Ore Geol. Rev. 2016, 78, 151-165. [CrossRef]

101. Gagnon, J.E.; Samson, I.M.; Fryer, B.J.; Williams-Jones, A.E. Compositional heterogeneity in fluorite and the genesis of fluorite deposits: Insights from LA-ICP-MS analysis. Can. Mineral. 2003, 41, 365-382. [CrossRef]

102. Dare, S.A.S.; Barnes, S.J.; Prichard, H.M. The distribution of platinum group elements (PGE) and other chalcophile elements among sulfides from the Creighton Ni-Cu-PGE sulfide deposit, Sudbury, Canada, and the origin of palladium in pentlandite. Mineral. Depos. 2010, 45, 765-793. [CrossRef]

103. Dare, S.A.S.; Barnes, S.J.; Prichard, H.M.; Fisher, P.C. Chalcophile and platinum-group element (PGE) concentrations in the sulfide minerals from the McCreedy East deposit, Sudbury, Canada, and the origin of PGE in pyrite. Mineral. Depos. 2011, 46, 381-407. [CrossRef]

104. Dare, S.A.S.; Barnes, S.J.; Beaudoin, G. Variation in trace element content of magnetite crystallized from fractionating sulfide liquid, Sudbury, Canada: Implications for provenance discrimination. Geochim. Cosmochim. Acta 2012, 88, 27-50. [CrossRef]

105. Dare, S.A.S.; Barnes, S.J.; Prichard, H.M.; Fisher, P.C. Mineralogy and geochemistry of Cu-rich ores from the McCreedy East Ni-Cu-PGE deposit (Sudbury, Canada): Implications for the behavior of platinum group and chalcophile elements at the end of crystallization of a sulfide liquid. Econ. Geol. 2014, 109, 343-366. [CrossRef] 
106. Duran, C.J.; Barnes, S.J.; Corkery, J.T. Chalcophile and platinum-group element distribution in pyrites from the sulfide-rich pods of the Lac des Iles Pd deposits, Western Ontario, Canada: Implications for post-cumulus re-equilibration of the ore and the use of pyrite compositions in exploration. J. Geochem. Explor. 2015, 158, 223-242. [CrossRef]

107. Godel, B.; Barnes, S.J. Platinum-group elements in sulfide minerals and the whole rock of the J-M Reef (Stillwater complex): Implication for the formation of the reef. Chem. Geol. 2008, 24, 272-294. [CrossRef]

108. Godel, B.; Barnes, S.J.; Maier, W.D. Platinum-group elements in sulphide minerals, platinum-group minerals, and whole-rocks of the Merensky Reef (Bushveld Complex, South Africa): Implications for the formation of the reef. J. Petrol. 2007, 48, 1569-1604. [CrossRef]

109. Holwell, D.A.; Keays, R.R.; McDonald, I.; Williams, M.R. Extreme enrichment of Se, Te, PGE and Au in $\mathrm{Cu}$ sulfide microdroplets: Evidence from LA-ICP-MS analysis of sulfides in the Skaergaard Intrusion, east Greenland. Contrib. Mineral. Petrol. 2015, 170, 1-26. [CrossRef]

110. Piña, R.; Gervilla, F.; Barnes, S.J.; Ortega, L.; Lunar, R. Partition coefficients of platinum group and chalcophile elements between arsenide and sulfide phases as determined in the Beni Bousera Cr-Ni mineralization (North Morocco). Econ. Geol. 2013, 108, 935-951. [CrossRef]

111. Piña, R.; Gervilla, F.; Barnes, S.J.; Ortega, L.; Lunar, R. Liquid immiscibility between arsenide and sulfide melts: Evidence from a LA-ICP-MS study in magmatic deposits at Serranía de Ronda (Spain). Mineral. Depos. 2015, 50, 265-279. [CrossRef]

112. Piña, R.; Gervilla, F.; Barnes, S.J.; Oberthür, T.; Lunar, R. Platinum-group element concentrations in pyrite from the Main Sulfide Zone of the Great Dyke of Zimbabwe. Mineral. Depos. 2016, in press.

113. Duran, C.J.; Barnes, S.-J.; Corkery, J.T. Trace element distribution in primary sulfides and Fe-Ti oxides from the sulfide-rich pods of the Lac des Iles Pd deposits, Western Ontario, Canada: Constraints on processes controlling the composition of the ore and the use of pentlandite compositions in exploration. J. Geochem. Explor. 2016, 166, 45-63.

114. Nikolakopoulos, D. Ore vectoring in IOCG Systems: Trace Elements in Garnets from the Groundhog Skarn, Punt Hill, South Australia. Unpublished Bachelor's Thesis, The University of Adelaide, Adelaide, Australia, 2013.

115. Peng, H.J.; Zhang, C.Q.; Mao, J.W.; Santosh, M.; Zhou, Y.M. Garnets in porphyry-skarn systems: A LA-ICP-MS, fluid inclusion, and stable isotope study of garnets from the Hongniu-Hongshan copper deposit, Zhongdian area, NW Yunnan Province, China. J. Asian Earth Sci. 2015, 103, 229-251. [CrossRef]

116. Zhao, W.W.; Zhou, M.F. In-situ LA-ICP-MS trace elemental analyses of magnetite: The Mesozoic Tengtie skarn Fe deposit in the Nanling Range, South China. Ore Geol. Rev. 2015, 65, 872-883. [CrossRef]

117. Groves, D.I.; Bierlein, F.P.; Meinert, L.D.; Hitzman, M.W. Iron oxide copper-gold (IOCG) deposits through earth history: Implications for origin, lithospheric setting, and distinction from other epigenetic iron oxide deposits. Econ. Geol. 2010, 105, 641-654. [CrossRef]

118. Huang, X.W.; Zhou, M.F.; Qiu, Y.Z.; Qi, L. In-situ LA-ICP-MS trace elemental analyses of magnetite: The Bayan Obo Fe-REE-Nb deposit, North China. Ore Geol. Rev. 2015, 65, 884-899. [CrossRef]

119. Knipping, J.L.; Bilenker, L.D.; Simon, A.C.; Reich, M.; Barra, F.; Deditius, A.P.; Heinrich, C.A.; Holtz, F.; Munizaga, R. Trace elements in magnetite from massive iron oxide apatite deposits indicate a combined formation by igneous and magmatic hydrothermal processes. Geochim. Cosmochim. Acta 2015, 171, 15-38. [CrossRef]

120. Tollari, N.; Barnes, S.-J.; Cox, R.A.; Nabil, H. Trace element concentrations in apatites from the Sept-Îles Intrusive Suite, Canada-Implications for the genesis of nelsonites. Chem. Geol. 2008, 252, 180-190. [CrossRef]

121. Chen, W.T.; Zhou, M.F.; Li, X.C.; Gao, J.F.; Hou, K.J. In-situ LA-ICP-MS trace elemental analyses of magnetite: $\mathrm{Cu}-(\mathrm{Au}, \mathrm{Fe})$ deposits in the Khetri copper belt in Rajasthan Province, NW India. Ore Geol. Rev. 2015, 65, 929-939. [CrossRef]

122. Ciobanu, C.L.; Cook, N.J.; Ehrig, K.; Wade, B.P.; Kamenetsky, V.S. Trace element signatures in iron oxides from the Olympic Dam IOCG deposit, South Australia. In Proceedings of the $13^{\text {th }}$ Biennial SGA Meeting, Mineral Resources in a Sustainable World, Nancy, France, 24-27 August 2015; Volume 3, pp. 1071-1074. 
123. Ehrig, K.; McPhie, J.; Kamenetsky, V. Geology and mineralogical zonation of the Olympic Dam Iron Oxide $\mathrm{Cu}-\mathrm{U}-\mathrm{Au}-\mathrm{Ag}$ deposit, South Australia. In Geology and Genesis of Major Copper Deposits and Districts of the World: A Tribute to Richard H. Sillitoe; Hedenquist, J.W., Harris, M., Camus, F., Eds.; Society of Economic Geologists Special Publication: Littleton, CO, USA, 2012; pp. 237-267.

124. Dupuis, C.; Beaudoin, G. Discrimination diagrams for iron oxide trace element fingerprinting of mineral deposit types. Mineral. Depos. 2011, 46, 319-335. [CrossRef]

125. Krneta, S.; Ciobanu, C.L.; Cook, N.J.; Ehrig, K.; Kamenetsky, V.S. REY-Signatures in Apatite Monitor Evolution of IOCG Systems: Examples from Olympic Dam and Acropolis, South Australia; Abstract; Australian Earth Science Convention: Adelaide, Australia, 2016.

126. Dare, S.A.S.; Barnes, S.J.; Beaudoin, G. Did the massive magnetite "lava flows" of El Laco (Chile) form by magmatic or hydrothermal processes? New constraints from magnetite composition by LA-ICP-MS. Mineral. Depos. 2015, 50, 607-617. [CrossRef]

127. Thomas, H.V.; Large, R.R.; Bull, S.W.; Maslennikov, V.; Berry, R.F.; Fraser, R.; Froud, S.; Moye, R. Pyrite and pyrrhotite textures and composition in sediments, laminated quartz veins, and reefs at Bendigo Gold Mine, Australia: Insights for ore genesis. Econ. Geol. 2011, 106, 1-31. [CrossRef]

128. Deol, S.; Deb, M.; Large, R.R.; Gilbert, S. LA-ICPMS and EPMA studies of pyrite, arsenopyrite and loellingite from the Bhukia-Jagpura gold prospect, southern Rajasthan, India: Implications for ore genesis and gold remobilization. Chem. Geol. 2012, 326-327, 72-87. [CrossRef]

129. Large, R.R.; Meffre, S.; Burnett, R.; Guy, B.; Bull, S.; Gilbert, S.; Goemann, K.; Danyushevsky, L. Evidence for an intrabasinal source and multiple concentration processes in the formation of the Carbon Leader Reef, Witwatersrand Supergroup, South Africa. Econ. Geol. 2013, 108, 1215-1241. [CrossRef]

130. Gregory, D.D.; Large, R.R.; Halpin, J.A.; Lounejeva Baturina, E.; Lyons, T.W.; Wu, S.; Danyushevsky, L.; Sack, P.J.; Chappaz, A.; Maslennikov, V.V.; et al. Trace element content of sedimentary pyrite in black shales. Econ. Geol. 2015, 110, 1389-1410. [CrossRef]

131. Steadman, J.A.; Large, R.R.; Meffre, S.; Olin, P.H.; Danyushevsky, L.V.; Gregory, D.D.; Belousov, I.; Lounejeva, E.; Ireland, T.R.; Holden, P. Synsedimentary to early diagenetic gold in black shale-hosted pyrite nodules at the golden mile deposit, Kalgoorlie, Western Australia. Econ. Geol. 2015, 110, 1157-1191. [CrossRef]

132. Genna, D.; Gaboury, D. Deciphering the hydrothermal evolution of a VMS system by LA-ICP-MS using trace elements in pyrite: An example from the Bracemac-Mcleod deposits, Abitibi, Canada, and Implications for Exploration. Econ. Geol. 2015, 110, 2087-2108. [CrossRef]

133. Mills, S.E.; Tomkins, A.G.; Weinberg, R.F.; Fan, H.R. Implications of pyrite geochemistry for gold mineralisation and remobilisation in the Jiaodong gold district, northeast China. Ore Geol. Rev. 2015, 71, 150-168. [CrossRef]

134. Boutroy, E.; Dare, S.A.S.; Beaudoin, G.; Barnes, S.J.; Lightfoot, P.C. Magnetite composition in Ni-Cu-PGE deposits worldwide: Application to mineral exploration. J. Geochem. Explor. 2014, 145, 64-81. [CrossRef]

135. Le Vaillant, M.; Barnes, S.J.; Fiorentini, M.L.; Miller, J.; McCuaig, T.C.; Muccilli, P. A hydrothermal Ni-As-PGE geochemical halo around the miitel komatiite-hosted nickel sulfide deposit, Yilgarn Craton, Western Australia. Econ. Geol. 2015, 110, 505-530. [CrossRef]

136. Acosta-Góngora, P.; Gleeson, S.A.; Samson, I.M.; Ootes, L.; Corriveau, L. Trace Element geochemistry of magnetite and its relationship to $\mathrm{Cu}-\mathrm{Bi}-\mathrm{Co}-\mathrm{Au}-\mathrm{Ag}-\mathrm{U}-\mathrm{W}$ mineralization in the great bear magmatic zone, NWT, Canada. Econ. Geol. 2015, 109, 1901-1928. [CrossRef]

137. Belousov, I.; Large, R.R.; Meffre, S.; Danyushevsky, L.V.; Steadman, J.; Beardsmore, T. Pyrite compositions from VHMS and orogenic Au deposits in the Yilgarn Craton, Western Australia: Implications for gold and copper exploration. Ore Geol. Rev. 2016, 79, 474-499. [CrossRef]

138. Canil, D.; Grondahl, C.; Lacourse, T.; Pisiak, L.K. Trace elements in magnetite from porphyry Cu-Mo-Au deposits in British Columbia, Canada. Ore Geol. Rev. 2016, 72, 1116-1128. [CrossRef]

139. Nadoll, P.; Mauk, J.L.; Hayes, T.S.; Koenig, A.E.; Box, S.E. Geochemistry of magnetite from hydrothermal ore deposits and host rocks of the mesoproterozoic belt supergroup, United States. Econ. Geol. 2012, 107, 1275-1292. [CrossRef]

140. Hanley, J.J.; Bray, C.J. The trace metal content of amphibole as a proximity indicator for Cu-Ni-PGE mineralization in the footwall of the Sudbury Igneous Complex, Ontario, Canada. Econ. Geol. 2009, 104, 113-125. [CrossRef] 
141. Warren, M.R.; Hanley, J.J.; Ames, D.E.; Jackson, S.E. The Ni-Cr-Cu content of biotite as pathfinder elements for magmatic sulfide exploration associated with mafic units of the Sudbury Igneous Complex, Ontario, Canada. J. Geochem. Explor. 2015, 153, 11-29. [CrossRef]

142. Wilkinson, J.J.; Chang, Z.; Cooke, D.R.; Baker, M.J.; Wilkinson, C.C.; Inglis, S.; Chen, H.; Gemmell, J.B. The chlorite proximitor: A new tool for detecting porphyry ore deposits. J. Geochem. Explor. 2015, 152, 10-26. [CrossRef]

143. Mao, M.; Rukhlov, A.S.; Rowins, S.M.; Spence, J.; Coogan, L.A. Apatite trace element compositions: A robust new tool for mineral exploration. Econ. Geol. 2016, 111, 1043-1072. [CrossRef]

144. Makvandi, S.; Ghasemzadeh-Barvarz, M.; Beaudoin, G.; Grunsky, E.C.; McClenaghan, M.B.; Duchesne, C. Principal component analysis of magnetite composition from volcanogenic massive sulfide deposits: Case studies from the Izok Lake (Nunavut, Canada) and Halfmile Lake (New Brunswick, Canada) deposits. Ore Geol. Rev. 2016, 72, 60-85. [CrossRef]

145. Makvandi, S.; Ghasemzadeh-Barvarz, M.; Beaudoin, G.; Grunsky, E.C.; McClenaghan, M.B.; Duchesne, C.; Boutroy, E. Partial least squares-discriminant analysis of trace element compositions of magnetite from various VMS deposit subtypes: Application to mineral exploration. Ore Geol. Rev. 2016, 78, 388-408. [CrossRef]

146. Lane, D.J.; Cook, N.J.; Grano, S.R.; Ehrig, K. Selective leaching of penalty elements from copper concentrates: A review. Miner. Eng. 2016, 98, 110-121. [CrossRef]

147. Andersen, J.C.Ø.; Stickland, R.J.; Rollinson, G.K.; Shail, R.K. Indium mineralisation in SW England: Host parageneses and mineralogical relations. Ore Geol. Rev. 2016, 78, 213-238. [CrossRef]

148. Pavlova, G.G.; Palessky, S.V.; Borisenko, A.S.; Vladimirov, A.G.; Seifert, T.; Phan, L.A. Indium in cassiterite and ores of tin deposits. Ore Geol. Rev. 2015, 66, 99-113. [CrossRef]

149. Cook, N.J.; Ciobanu, C.L. Mineral hosts for critical metals in hydrothermal ores. In Mineral Resources in a Sustainable World, Proceedings of the 13th Biennial SGA Conference, Nancy, France, 24-27 August 2015; Volume 5, pp. 707-710.

150. Dalpé, C.; Hudon, P.; Ballantyne, D.J.; Williams, D.; Marcotte, D. Trace element analysis of rough diamond by LA-ICP-MS: A case of source discrimination? J. Forensic Sci. 2010, 55, 1443-1456.

151. Coney, L.; Moila, A.V.; Quadling, A.G. Gem-quality diamonds: Source discrimination. S. Afr. J. Geol. 2012, 115, 33-46. [CrossRef]

152. Melcher, F.; Graupner, T.; Henjes-Kunst, F.; Oberthür, T.; Sitnikova, M.; Gäbler, H.E. Analytical fingerprint of columbite-tantalite (coltan) mineralization in pegmatites: Focus on Africa. In Proceedings of the 9th International Congress for Applied Mineralogy, Australasian Institute of Mining and Metallurgy, Melbourne, Australia, 8-10 September 2008; pp. 615-624.

153. Gäbler, H.E.; Rehder, S.; Bahr, A.; Melcher, F.; Goldmann, S. Cassiterite fingerprinting by LA-ICP-MS. J. Anal. Atom. Spectrom. 2013, 28, 1247-1255. [CrossRef]

154. Giussani, B.; Monticelli, D.; Rampazzi, L. Role of laser ablation-inductively coupled plasma-mass spectrometry in cultural heritage research: A review. Anal. Chim. Acta 2009, 635, 6-21. [CrossRef] [PubMed]

155. De Marques Sá, C.; Noronha, F.; Ferreira da Silva, E. Factor analysis characterization of minor element contents in sulfides from $\mathrm{Pb}-\mathrm{Zn}-\mathrm{Cu}-\mathrm{Ag}$ hydrothermal vein deposits in Portugal. Ore Geol. Rev. 2014, 62, 54-71. [CrossRef]

156. Frenzel, M.; Hirsch, T.; Gutzmer, J. Gallium, germanium, indium, and other trace and minor elements in sphalerite as a function of deposit type-A meta-analysis. Ore Geol. Rev. 2016, 76, 52-78. [CrossRef]

157. Debruyne, D.; Hulsbosch, N.; Muchez, P. Unraveling rare earth element signatures in hydrothermal carbonate minerals using a source-Sink system. Ore Geol. Rev. 2016, 72, 232-252. [CrossRef]

158. Li, X.F.; Cheng, H.; Wang, C.Z.; Wang, L. Genesis of the Huangshaping W-Mo-Cu-Pb-Zn polymetallic deposit in Southeastern Hunan Province, China: Constraints from fluid inclusions, trace elements, and isotopes. Ore Geol. Rev. 2016, 79, 1-25.

159. Xu, L.; Bi, X.; Hu, R.; Tang, Y.; Wang, X.; Xu, Y. LA-ICP-MS mineral chemistry of titanite and the geological implications for exploration of porphyry $\mathrm{Cu}$ deposits in the Jinshajiang-Red River alkaline igneous belt, SW China. Mineral. Petrol. 2015, 109, 181-200. [CrossRef]

160. Jaques, A.L. Major and trace element variations in oxide and titanate minerals in the West Kimberley lamproites, Western Australia. Mineral. Petrol. 2016, 110, 159-197. [CrossRef] 
161. Velasquez, A. Trace Element Analysis of Native Gold by Laser Ablation ICP-MS: A Case Study in Greenstone-Hosted Quartz-Carbonate Vein Ore Deposits, Timmins, Ontario. Ph.D. Thesis, University of British Columbia, Kelowna, BC, Canada, 2014.

162. Kołodziejczyk, J.; Pršek, J.; Voudouris, P.; Melfos, V.; Asllani, B. Sn-bearing minerals and associated sphalerite from lead-zinc deposits, Kosovo: An electron microprobe and LA-ICP-MS study. Minerals 2016, 6, 42. [CrossRef]

163. Ciobanu, C.L.; Cook, N.J.; Maunders, C.; Wade, B.P.; Ehrig, K. Focused ion beam and advanced electron microscopy for minerals: Insights and outlook from bismuth sulphosalts. Minerals 2016, 6, 112.

164. Baele, J.-M.; Monin, L.; Navez, J.; André, L. Systematic REE Partitioning in Cubo-Dodecahedral Fluorite from Belgium Revealed by Cathodoluminescence Spectral Imaging and Laser Ablation-ICP-MS. In Proceedings of the 10th International Congress for Applied Mineralogy (ICAM), Trondheim, Norway, 1-5 August 2011; Springer: Berlin, Germany, 2012.

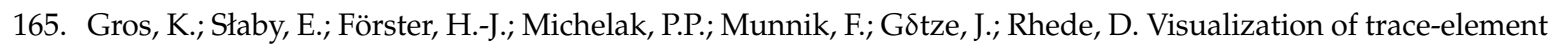
zoning in fluorapatite using BSE and CL imaging, and EPMA and $\mu$ PIXE/ $\mu$ PIGE mapping. Mineral. Petrol. 2016. [CrossRef]

166. Garbe-Schönberg, D.; Müller, S. Nano-particulate pressed powder tablets for LA-ICP-MS. J. Anal. Atom. Spectrom. 2014, 29, 990-1000. [CrossRef]

167. Garbe-Schönberg, D.; Müller, S.; Nordstad, S.; Schönberg, L. Particle size matters: A new strategy for manufacturing microanalytical reference standards from nano-particulate powder pellets. In Proceedings of the 9th International Conference on the Analysis of Geological and Environmental Materials, Leoben, Austria, 8-14 August 2015; Abstract OP-25, p. 64.

168. Onuk, P.; Melcher, F.; Walkner, C. Development of the matrix-matched sphalerite (ZnS) standards MUL-ZnS-1 and MUL-ZnS-2 for in-situ analysis of trace elements by laser ablation inductively coupled plasma-mass spectroscopy (LA-ICP-MS). In Proceedings of the 9th International Conference on the Analysis of Geological and Environmental Materials, Leoben, Austria, 8-14 August 2015; Abstract OP-26, p. 65.

169. Savard, D.; Raymond, V.; Barnes, S.J. LA-ICP-MS analysis of massive sulphides: Progress towards a new calibration material. In Proceedings of the 9th International Conference on the Analysis of Geological and Environmental Materials, Leoben, Austria, 8-14 August 2015; Abstract P-39, p. 116.

(C) 2016 by the authors; licensee MDPI, Basel, Switzerland. This article is an open access article distributed under the terms and conditions of the Creative Commons Attribution (CC-BY) license (http://creativecommons.org/licenses/by/4.0/). 